\title{
The sapphirine-bearing rocks in contact with the Lherz peridotite body: New mineralogical data, age and interpretation
}

\author{
Jessica Uzel ${ }^{1, *}$, Yves Lagabrielle ${ }^{1}$, Serge Fourcade ${ }^{1}$, Christian Chopin $^{2}$, Pierre Monchoux ${ }^{3}$, \\ Camille Clerc ${ }^{4}$ and Marc Poujol ${ }^{1}$ \\ ${ }^{1}$ Univ Rennes, CNRS, Géosciences Rennes, UMR 6118, 35000 Rennes, France \\ 2 Laboratoire de Géologie de l'ENS, UMR 8538, ENS-CNRS, PSL Research University, 24, rue Lhomond, 75005 Paris, France \\ ${ }^{3}$ Université de Toulouse, CNRS, GET, IRD, OMP, 14, avenue Edouard Belin, 31400 Toulouse, France \\ ${ }^{4}$ Laboratoire Insulaire du Vivant et de l'Environnement, Université de la Nouvelle Calédonie, BPR4, 98851 Nouméa cedex, France
}

Received: 28 December 2018 / Accepted: 5 November 2019

\begin{abstract}
Sapphirine-bearing rocks are described in the Aulus Basin (Ariège, France) in a contact zone between the Lherz peridotitic body and Mesozoic metasediments which underwent the Pyrenean Cretaceous high-temperature, low-pressure metamorphic event (Monchoux, 1970, 1972a, 1972b). Sapphirine crystals occur in layered clastic deposits characterized by an uncommon suite of Al-Mg-rich minerals. A detailed petrographic study of sixteen samples representative of the diversity of the Lherz sapphirine-bearing rocks is presented. These rocks include breccias and microbreccias with various compositions. Some samples are composed of polymineralic clasts and isolated minerals that derive from regionally well-known protoliths such as ultramafic rocks, meta-ophites, "micaceous hornfels", and very scarce Paleozoic basement rocks. Nevertheless, a large portion of the sapphirine-bearing clastic suite is composed of mono- and polymineralic debris that derive from unknown protolith(s). We define a "sapphirine-bearing mineral suite" (SBMS) composed of monomineralic debris including: sapphirine + enstatite + aluminous spinel $+\mathrm{Mg}-$ amphiboles + Ca-amphiboles + kornerupine + accessory minerals (apatite, diopside, rutile, serpentine, smectite, tourmaline, vermiculite and a white mica). We highlight the dominance of metamorphic Keuper clastic materials in the studied rocks and the presence of inclusions of anhydrite and F-, Cl-, Sr-rich apatite in minerals of the Al-Mg-rich suite. The brecciated texture and the presence of unequivocal sedimentary features suggest that the sapphirine-bearing rocks were mechanically disaggregated and then experienced winnowing in underwater conditions with poor mixing between the different sources. We measured U-Pb rutile age data in order to provide constraints on the age of (one of) the protolith(s) of those clastic deposits. The obtained age $(98.6+1.2 \mathrm{Ma})$ is interpreted as the age of metamorphism of this protolith of the SBMS. Previous works interpreted the Lherz sapphirine-bearing rocks as crustal protoliths modified at depth along the contact with the ultramafic rocks of the Lherz body during their ascent towards shallower depths. These new data imply: (i) an Upper Triassic to Lower Jurassic origin for the main protolith of the sapphirinebearing rocks; (ii) the metamorphism of this protolith along an active hot crust-mantle detachment during Cenomanian times with the involvement of metasomatic, brine-type fluids; and (iii) its brecciation during the exhumation of the material due to the evolution of the detachment, followed by subsequent sedimentary reworking of the metamorphic material.
\end{abstract}

Keywords: North Pyrenean zone / sapphirine / Keuper / meta-evaporite / high-temperature low-pressure metamorphism / mantle exhumation / extensional detachment

Résumé - Les roches à saphirine au contact du corps de péridotites de Lherz: nouvelles données minéralogiques, âge et nouvelle interprétation. Des roches contenant de la saphirine ont été décrites dans le Bassin d'Aulus (Ariège, France), au sein d'une zone de contact entre le corps de péridotites de Lherz et les métasédiments mésozoïques affectés au Crétacé par un métamorphisme de haute température et de basse pression (Monchoux, 1970, 1972a, 1972b). La saphirine se trouve dans des dépôts clastiques lités caractérisés par une association minérale rare, riche en $\mathrm{Al}$ et $\mathrm{Mg}$. Nous présentons ici les résultats de l'étude

*Correspondence: jessica.uzel@univ-rennes1.fr 
pétrographique détaillée de 16 échantillons représentatifs de la diversité des roches à saphirine de Lherz. Ces brèches et microbrèches sont constituées de clastes monominéraux et polyminéraux de composition variable. Les protolithes de certains de ces clastes sont aisément identifiables : roches ultramafiques, métaophites, «cornéennes micacées », socle paléozoïque. Néanmoins, une grande partie des roches à saphirine est composée de débris mono- et polyminéraux dont le ou les protolithes sont inconnus dans la région et restent à identifier. Ces protolithes énigmatiques sont nécessairement composés des minéraux de l'ensemble que nous appelons «assemblage minéralogique à saphirine» (sapphirine-bearing mineral suite: SBMS) et qui comprend les espèces suivantes : saphirine + enstatite + spinelle alumineux $+\mathrm{Mg}$-amphiboles $+\mathrm{Ca}-$ amphiboles + kornérupine + minéraux accessoires (apatite, diopside, rutile, serpentine, smectite, tourmaline, vermiculite et mica blanc). Nous mettons en évidence la présence d'inclusions d'anhydrite et d'apatite riche en $\mathrm{F}, \mathrm{Cl}$ et $\mathrm{Sr}$ dans les espèces minérales du SBMS, ainsi qu'une proportion dominante d'éléments clastiques issus du métamorphisme de roches du Keuper dans l'ensemble des échantillons étudiés. La texture bréchique ainsi que la présence de figures sédimentaires dans les roches à saphirine montrent que leur(s) protolithe(s) a (ont) été soumis à un processus de désagrégation mécanique suivi du vannage des clastes en milieu aqueux. Un faible mélange entre les différentes sources est établi par la composition lithologique des roches étudiées. Une étude géochronologique par la méthode U-Pb sur rutile a été réalisée afin d'apporter des contraintes sur l'âge d'une (ou de la) source de ces dépôts clastiques. L'âge obtenu (98,6 + 1,2 Ma) est interprété comme l'âge du métamorphisme de ce protolithe du SBMS. Les roches à saphirine ont jusqu'à présent été interprétées comme du matériel crustal modifié en profondeur au contact des roches ultramafiques du corps de Lherz lors de leur remontée vers la surface. Les nouvelles contraintes géologiques apportées par cette étude impliquent : (i) l'origine triasique supérieure à jurassique inférieure du protolithe principal des roches à saphirine; (ii) le métamorphisme de ce protolithe en présence de saumures le long d'un détachement croûte-manteau actif et chaud au Cénomanien; et (iii) sa bréchification au cours de la remontée du matériel associée au fonctionnement du détachement, suivie du remaniement sédimentaire ultérieur de ce matériel métamorphique.

Mots-clés : Zone nord-pyrénéenne / saphirine / Keuper / méta-évaporite / métamorphisme de haute température et basse pression / exhumation du manteau / détachement extensif

\section{Introduction}

Sapphirine ([Mg,Fe, $\mathrm{Al}]_{8} \mathrm{O}_{2}[\mathrm{Al}, \mathrm{Si}]_{6} \mathrm{O}_{18} ;$ Moore, 1969) is a relatively rare mineral which records either ultrahigh-temperature conditions in silica-rich systems (Harley \& Motoyoshi, 2000; Wheller \& Powell, 2014) or high temperature and intermediate pressure conditions in silica-poor systems. In the absence of quartz, sapphirine is described as the product of metamorphic evolution of three main types of protoliths, namely: mafic and ultramafic rocks (Morishita et al., 2001; Jöns and Schenk, 2008; Feneyrol, 2012), crustal rocks (Arima and Barnett, 1984), and evaporitic deposits or metasomatic assemblages implying fluids (Schreyer and Abraham, 1976; Grew, 1988; Harley, 1993; Engvik and Austrheim, 2010). In the Pyrenean belt, Monchoux (1969) first described sapphirine at the northern edge of the Étang de Lherz lherzolite body, more commonly called the Lherz body (Ariège, France; Fig. 1), in a context involving both ultramafic rocks and metasediments. There, sapphirine crystals occur in layered clastic deposits characterized by uncommon mineral associations including $\mathrm{Mg}$ amphibole, aluminous orthopyroxene, spinel and kornerupine, which is a rare boron-bearing sorosilicate $\left(\mathrm{Mg}_{3} \mathrm{Al}_{6}[\mathrm{Si}, \mathrm{Al}\right.$, $\mathrm{B}]_{5} \mathrm{O}_{21}[\mathrm{OH}]$; Grew et al., 1990; Hawthorne et al., 2009). This clastic assemblage consists of polymictic breccias and sandstones exposed in a contact zone between the lherzolites and Mesozoic metasediments, mainly marbles (Monchoux, 1969). These marbles underwent the high-temperature, low-pressure (HT-LP) Mid-Cretaceous Pyrenean metamorphic event which is recognized all along the North Pyrenean Zone (NPZ; Ravier, 1959; Albarède and Michard-Vitrac, 1978; Montigny et al., 1986; Golberg and Maluski, 1988; Dauteuil and Ricou, 1989;
Golberg and Leyreloup, 1990; Clerc and Lagabrielle, 2014; Clerc et al., 2015; Ducoux, 2017). Golberg and Leyreloup (1990) were the first to ascribe this metamorphic event to a crustal thinning episode in the future NPZ.

The Lherz sapphirine-bearing rocks were first interpreted as deriving from lower continental crust lithologies modified at depth along the contact with the ultramafic rocks of the Lherz body during their ascent towards shallower depths (Monchoux, 1970, 1972a). This interpretation needs to be revisited because back then, the processes leading to mantle exposure at the Earth's surface were poorly understood and models of subcontinental mantle exhumation along detachment faults were not yet applied to the Pyrenean case (Lagabrielle and Bodinier, 2008; Jammes et al., 2009; Duretz et al., 2019). In addition, the North Pyrenean Cretaceous metamorphic event was not recognized as the result of crustal thinning but was thought to be related to the early compressional phases of the Pyrenean orogeny (Choukroune, 1970; Debroas, 1978).

The occurrence of mantle outcrops in the distal part of passive continental margins is now extensively documented (e.g., Boillot et al., 1980; Espurt et al., 2009; Gillard et al., 2016; Péron-Pinvidic and Osmundsen, 2016). These recent advances allow for fruitful comparisons between passive margins and some units of the Pyrenean belt and thus provide key arguments to unravel the significance of the geological associations found in the vicinity of mantle exposures in the NPZ (e.g., Masini et al., 2014; Tugend et al., 2015; Corre et al., 2016). In this paper, we present the results of a detailed petrographic study of the formations exposed at the northern border of the Lherz body, in two of the sites where Monchoux (1970, 1972a, 1972b) described the sapphirine-bearing rocks. 


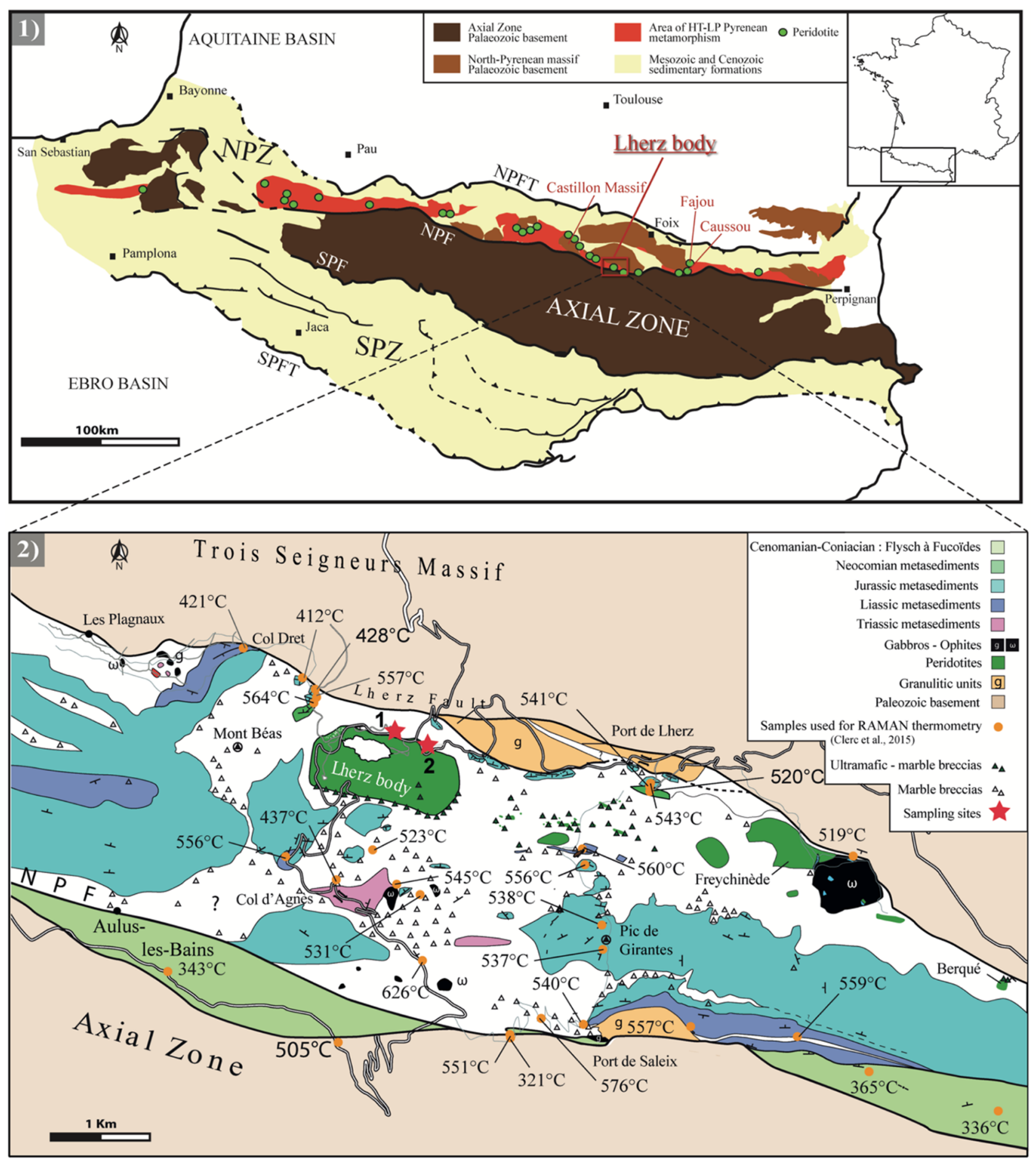

Fig. 1. (1) Geological sketch map of the Pyrenees showing the location of the Lherz body. NPFT: North-Pyrenean Frontal Thrust; NPF: NorthPyrenean Fault; SPF: South-Pyrenean Fault; SPFT: South Pyrenean Frontal Thrust; NPZ: North Pyrenean Zone; SPZ: South Pyrenean Zone (modified after Corre et al., 2016); (2) geological map of the Aulus Basin (modified after Lagabrielle et al., 2016). Locations of the studied sites 1 and 2 are indicated by red stars. Units of massive carbonates are separated by wide areas of polymictic sedimentary breccias. The ultramaficbearing breccias are restricted to the central part of the Aulus Basin where the peridotite bodies are concentrated. Peak temperatures obtained by RSCM (Raman spectroscopy of carbonaceous material) geothermometry on Mesozoic marble samples are from Clerc et al. (2015). Site 1: $42^{\circ} 48^{\prime} 30.52^{\prime \prime N} 1^{\circ} 22^{\prime} 52.85^{\prime \prime E}$. Site 2: 4248’26.78"N 1²3’7.97"E. 
Our aim is to identify the protolith(s) and the geological processes responsible for the formation of such uncommon mineral associations and to explain their juxtaposition with exhumed mantle peridotites.

\section{Geological setting}

\subsection{The North Pyrenean Zone and the Aulus Basin}

The Pyrenean belt results from the collision between the Eurasian and Iberian plates that started during the Santonian (Garrido-Megías, 1972; Olivet, 1996; García Senz, 2002; Rosenbaum et al., 2002; McClay et al., 2004; Handy et al., 2010). This double-verging orogen is classically divided into three main structural domains: the North and South Pyrenean Zones, composed of Mesozoic and Cenozoic sediments, and the Axial Zone exposing Paleozoic basement rocks. The Axial Zone is separated from the NPZ by the North Pyrenean Fault (NPF) (Fig. 1(1)). The NPZ is characterized by a series of inverted basins that opened in the Albian-Cenomanian times and that host about 40 different fragments of subcontinental peridotites (Lacroix, 1894; Bodinier et al., 1987; Fabriès et al., 1991; Henry et al., 1998). These mantle bodies crop out within Mesozoic metasediments that underwent a HT-LP metamorphic evolution that took place between the Albian and Santonian times (110-85 Ma: Albarède and Michard-Vitrac, 1978; Montigny et al., 1986; Golberg and Maluski, 1988; Clerc et al., 2015). The opening of the NPZ basins occurred in response to the counterclockwise rotation of Iberia, which was accommodated by a sinistral transtensional motion along the future NPF (Olivet, 1996; Sibuet et al., 2007; Gong et al., 2008). The NPZ also includes different isolated Paleozoic North Pyrenean Massifs (NPM) that represent remnants of its original continental basement. These massifs experienced three metamorphic episodes, namely the Hercynian, Permian and Cretaceous events. The Hercynian orogeny (ca. 350-300 Ma) in the Pyrenees is characterized by a polyphased deformation, accompanied by a HT-LP metamorphism, migmatization and granitic magmatism (Denèle et al., 2014). During the Permian, the opening of sedimentary basins in the Pyrenees (Bixel and Lucas, 1987; Lago et al., 2004; Saspiturry et al., 2019) induced reheating of the NPM (Bixel and Lucas, 1987; Briqueu and Innocent, 1993; Lago et al., 2004; Denèle et al., 2012; Asti et al., 2019). Then, the Cretaceous extensional event resulted in an early crustal thinning and in fragmentation of the NPM (Costa and Maluski, 1988; Vauchez et al., 2013). Evidence for major fluid circulations linked to this last thinning episode was found in some NPM, including talcenriched faults (Schärer et al., 1999; Boutin et al., 2016) and hydrothermal albitites (Boulvais et al., 2007; Poujol et al., 2010; Fallourd et al., 2014). The Albian-Santonian HT metamorphic event was assigned to the latter crustal thinning episode (Golberg and Leyreloup, 1990) and was further correlated to the exhumation of the subcontinental mantle rocks (Lagabrielle and Bodinier, 2008; Clerc and Lagabrielle, 2014). The peak-temperature estimates obtained for the extensional Cretaceous event in the NPZ using Raman spectroscopy of the carbonaceous matter (RSCM) were measured in the Mesozoic metasediments of the Aulus Basin
(Fig. 1(2)). Values are grouped around $550{ }^{\circ} \mathrm{C}$, reaching $625^{\circ} \mathrm{C}$ in one sample (Clerc et al., 2015).

During the past decade, the North Pyrenean subcontinental peridotite bodies have been repeatedly studied in order to unravel the processes of mantle exhumation in the Cretaceous Pyrenean basins (Lagabrielle and Bodinier, 2008; Jammes et al., 2009; Clerc et al., 2012; Clerc and Lagabrielle, 2014; De Saint Blanquat et al., 2016; Lagabrielle et al., 2016; DeFelipe et al., 2017; Lagabrielle et al., 2019). Several recent studies argue for a tectono-sedimentary model for the emplacement of the ultramafic rocks and associated breccias (Lagabrielle and Bodinier, 2008; Lagabrielle et al., 2010, 2016; Clerc et al., 2012; Clerc and Lagabrielle, 2014). In these models, the subcontinental Pyrenean mantle was exhumed along detachment faults and exposed locally on the floor of the narrow NPZ basins during the Cretaceous rifting event, under high thermal conditions.

Recent reconstructions based on geological investigations along the NPZ basins led to define a peculiar architecture for the Pyrenean paleo-passive margin controlled by a high thermal regime, thus contrasting with classical models of passive margins exemplified by the Iberia-Newfoundland case (Péron-Pinvidic and Manatschal, 2009). This led Clerc and Lagabrielle (2014) and Clerc et al. (2016) to propose a mechanism of rifting in the distal margin domain involving the boudinage of the continental crust under a mobile Mesozoic pre-rift cover detached from the basement along Late Triassic clays and evaporites decoupling layers. A more brittle behaviour characterizes the proximal margin domain. This model was corroborated by recent numerical modelling work (Duretz et al., 2019).

\subsection{Geological content and interpretations of the Lherz breccias}

The Aulus Basin exposes Mesozoic metasediments and two major ultramafic exposures: the Lherz and Freychinède bodies. Small gabbro and meta-ophite (Late Triassic mafic hypovolcanic rocks) bodies are also found in the vicinity of the ultramafics (Fig. 1(2)). Metasediments exposed close to both Lherz and Freychinède bodies are massive carbonates and breccias often referred to as the Lherz breccias (e.g., Lacroix, 1894; Choukroune, 1973, 1976; Ternet et al., 1997). Previous studies investigated in detail the petrography of the Lherz breccias and discussed their possible modes of emplacement either as sedimentary breccias (Lacroix, 1892; Choukroune, 1973), tectonic breccias (Lacroix, 1900; Ternet et al., 1997; Debroas et al., 2010), explosion breccias (Avé Lallemant et al., 1968; Minnigh et al., 1980), or tectono-sedimentary breccias (Lagabrielle et al., 2016 and references therein). These studies first pointed to the great variability in the breccia types which range from monomictic carbonate breccias to pure ultramafic breccias. Between these two end-members, polymictic breccias are composed of various proportions of ultramafic and Triassic to Early Cretaceous carbonate clasts (Clerc et al., 2012). The Lherz breccias also contain clasts of meta-ophite, enstatite-gabbro, and minor amounts of Paleozoic crustal rocks.

A progressive transition from the peridotite rocks to the surrounding breccias is observed around the Lherz and 
Freychinède bodies. At an increasing distance from the borders of the ultramafic bodies, one gradually observes:

- ultramafic breccias with a calcite-rich matrix (ophicalcites; Lagabrielle and Bodinier, 2008; Clerc et al., 2014);

- monomictic ultramafic breccias with an ultramafic-rich matrix;

- polymictic ultramafic and marble breccias and;

- monomictic marble breccias (Lacroix, 1894; Monchoux, 1970).

The age of deposition of the breccias is a matter of debate because of the lack of stratigraphic or paleontological constraints. The observation of cracks in the peridotite infilled by breccias indicates that deposition of breccias postdates or is synchronous with exhumation of the peridotite to the basin floor (Lagabrielle and Bodinier, 2008). Lherz breccias clasts are dominantly carbonates that underwent metamorphism leading to scapolite and amphibole-bearing foliated marbles. This implies a post-metamorphic or syn-metamorphic origin for the breccias deposition.

An anchizonal to epizonal thermal event leading to neoformation of muscovite and paragonite has been characterized in the carbonatic pelitic metasediments of the TuronianSenonian flysch of the Aulus Basin (80 Ma; Montigny et al., 1986). This is confirmed by peak metamorphic temperatures reaching $350{ }^{\circ} \mathrm{C}$ recently obtained in a tectonic slice of this flysch pinched along the southern rim of the Aulus Basin (Clerc et al., 2015). Dating results obtained in the NPZ show that the thermal anomaly affecting the north Pyrenean basins may have lasted from 107 to $80 \mathrm{Ma}$, i.e. during almost $27 \mathrm{My}$ (see complete references in Clerc et al., 2015). This time span is large enough for a succession of events to develop in the sedimentary cover of the Aulus Basin, including:

(i) high-temperature metamorphism during the ascent of the peridotites towards shallow levels;

(ii) exhumation and disaggregation to the seafloor, followed by sedimentation of the Lherz breccias;

(iii) diagenesis and renewed thermal metamorphism following burial under Late Cretaceous flysch sequences.

Lagabrielle et al. (2016) used the geological constraints summarized above to construct a tectono-sedimentary model for the emplacement of the NPZ peridotites and associated metasediments. This model contrasts with former interpretations of the Lherz body as tectonic slices or olistolith (e.g., Vielzeuf and Kornprobst, 1984; Lagabrielle et al., 2010). In their 2016's model, Lagabrielle et al. propose that the Lherz peridotite is exhumed along a detachment fault and thus represents the bottom of the Aulus Basin. The Mesozoic sedimentary formations, decoupled from the Palaeozoic basement, are juxtaposed on top of the Lherz body and thereby suffer metamorphism and deformation. Their brecciation and resedimentation occurs during their exhumation. This model considers most of the lithologies exposed in the Aulus Basin but it needs refinement since it does not account for the presence of the sapphirine-bearing rocks along the contact with the ultramafic rocks. Following Clerc et al. (2012) and further studies, the geological setting of the sapphirine-bearing rocks implies to consider this formation as the lowermost levels of the Lherz tectono-sedimentary breccias. Therefore, the sapphirinebearing rocks are good candidates to represent the first formation emplaced over the detachment fault that allowed the peridotite of the Lherz body to be exhumed towards upper crustal levels and finally exposed on the floor of the former Aulus Basin.

\section{Geological description of sampling sites and analytical methods}

The sixteen samples of sapphirine-bearing sandstones and breccias studied here were collected at two sites which were first described by P.Monchoux (exposures 1 and 3 in: Monchoux, 1970, 1972a, 1972b), hereafter referred to as sites 1 and 2 (Fig. 1(2) and 2(1)). The other exposures described by P. Monchoux, all located along the contact between the Lherz body and the Mesozoic marbles and breccias of the NPZ, have disappeared under the vegetation.

At site $1\left(42^{\circ} 48^{\prime} 30.52^{\prime \prime} \mathrm{N} 1^{\circ} 22^{\prime} 52.85^{\prime \prime} \mathrm{E}\right)$, the sapphirinebearing sandstones are present along an ancient road-cut, in front of the Etang de Lherz restaurant. The exposure has been cleared on a length of $8 \mathrm{~m}$. The sandstones and breccias form a layered sequence with a rough vertical bedding defined by alternating dark-brown, orange and light-grey layers (Fig. 2 (1)). The thickness of layers varies from some centimetres to one metre and variations in colours are clearly linked to variable lithological compositions. At first sight, the exposure displays four types of clastic layers, namely the A, B, C and D layers (sometimes recurrent) separated by rather sharp contacts (Fig. 2(1), (2)):

- Layer A is the dominant type. It corresponds to light grey, coarse sandstones composed of white and grey grains with planar to acicular outlines. Some of the grains show shinning cleavages, evoking micas and amphiboles. Based on $\mathrm{HCl}$ tests, some portions of Layer A contain calcite, others do not;

- Layer B corresponds to dark-brown layers of ultramafic breccias and microbreccias composed of dominant angular clasts of serpentinized lherzolite in a sandy matrix with an ultramafic composition. The largest clasts are up to $10 \mathrm{~cm}$ long (Fig. 2(2), (3));

- Layer C is represented by breccias and sandstones made of dominant ultramafic and minor $\mathrm{cm}$-sized clasts of a granoblastic mafic rock. The latter clasts, which exhibit $\mathrm{mm}$-sized white and black crystals, typically derive from the metamorphism of Triassic ophite (Azambre et al., 1987);

- Layer D is a coarse breccia made of a mix of the lithologies forming the previous $\mathrm{A}, \mathrm{B}$ and $\mathrm{C}$ layer types. It is composed of $\mathrm{cm}$ - to dm-sized angular clasts of ultramafic rock, white sandstones and microbreccias, and Late Triassic metaophites (Fig. 2(4)). It also includes clasts of a black rock spotted by white material corresponding to the so-called "micaceous hornfels" (“cornéennes micacées"; Lacroix, 1894) largely exposed some kilometres south of the studied exposures, at Col d'Agnès (Ternet et al., 1997). The "micaceous hornfels" have an unequivocal aspect and are composed of an association of scapolite and phlogopite which derive from the metamorphism of Upper Triassic to Lower Jurassic evaporitic clays during the Cretaceous HT Pyrenean event $(93 \pm 3 \mathrm{Ma}$; Ravier and Thiébaut, 1982; Montigny et al., 1986).

At site $2\left(42^{\circ} 48^{\prime} 26.78^{\prime \prime} \mathrm{N} 1^{\circ} 23^{\prime} 7.97 " \mathrm{E}\right)$, located along the north-eastern border of the Lherz body (Fig. 1(2)), a portion of the former exposure 3 described by Monchoux (1972a, 1972b) 

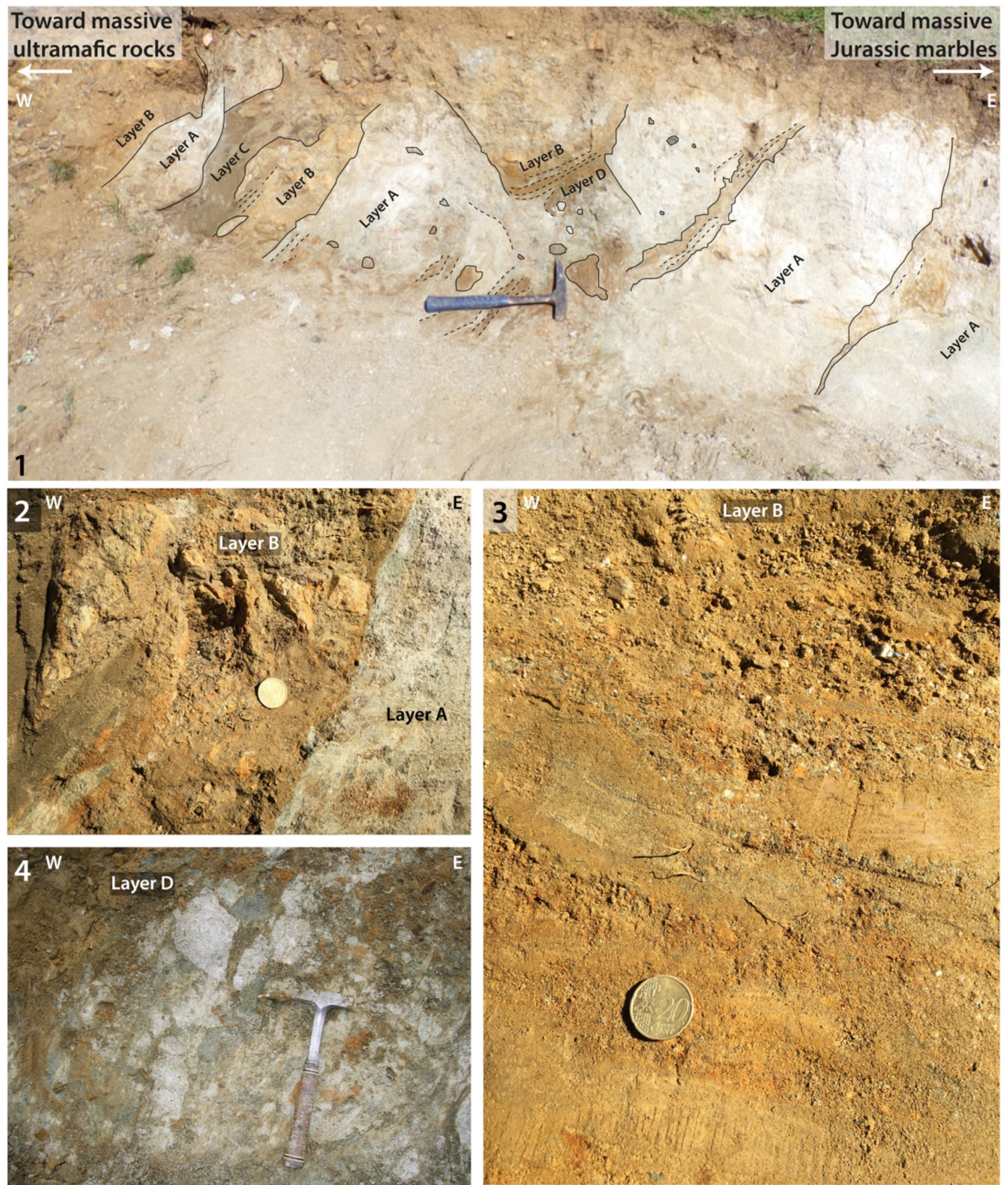

Fig. 2. Field photographs from site 1: (1) succession of clastic layers at site 1. Four layer types can be distinguished (see text for complete description). The dominant Layer A corresponds to light grey, coarse sandstones. Layer B corresponds to dark-brown layers of ultramafic breccias and microbreccias composed of dominant angular clasts of serpentinized lherzolite in an ultramafic sandy matrix. Layer $\mathrm{C}$ is represented by breccias and sandstones made of dominant ultramafic and minor cm-sized clasts of Triassic meta-ophite. Layer D is a coarse breccia composed of $\mathrm{cm}$ - to dm-sized angular clasts of ultramafic rock, white microbreccias, Triassic to Lower Jurassic meta-ophites and "micaceous hornfels"; (2) sharp contact between Layer B ultramafic breccias (left) and light-grey Layer A sandstones (right); (3) close-up of graddedbedding observed in Layer B microbreccias; (4) detail view of Layer D breccia. 

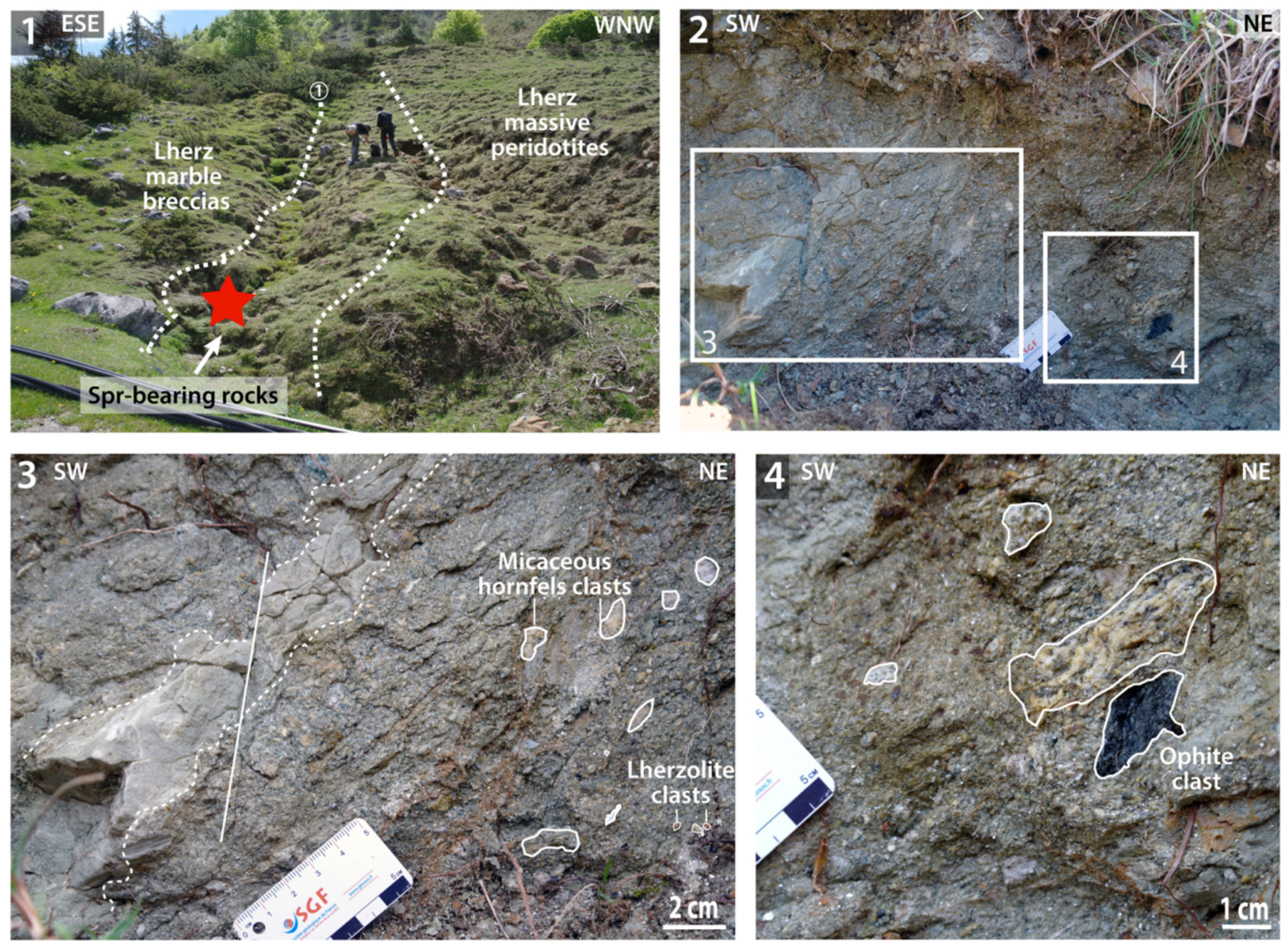

Fig. 3. Field photographs from site 2: (1) photograph of the contact zone between the mantle peridotites and the Lherz breccias at site 2 and location of the sapphirine-bearing rocks sampling site (red star). White dotted lines underline the progressive transition existing between the Lherz body and the Lherz marble breccias. Around white dotted line $\mathrm{n}^{\circ} 1$, a progressive transition from the sapphirine-bearing rocks to the pure marble breccias and microbreccias was observed; (2) detailed view of the sampling site 2 and location of close up photographs 3 and 4 shown below; (3) detailed view of the left side of exposure. It consists of a pale-green to light-grey microbreccia showing a rough bedding with layers of thin-grained sandstones dipping to the south-east (dashed lines). The microbreccia contains numerous cm-sized angular clasts of variable lithologies including "micaceous hornfels" and poorly serpentinized lherzolite (white outlines, determined on thin-sections); (4) detailed view of the right side of exposure. Sandstones include numerous cm-sized angular clasts of variable compositions (white outlines). One black clast of meta-ophite is observed macroscopically (bottom right side of photograph).

was partly cleared on both sides of a gully, over a few metres between outcrops of the massive peridotite and outcrops of pure marble breccias (Fig. 3(1), (4)). The outcrop consists of a palegreen to light-grey microbreccia showing a rough bedding dipping to the south-east. Sandstones layers are interbedded and crossed-stratification can be locally observed (Fig. 3(2) and (3)). The microbreccia contains numerous $\mathrm{dm}$-sized angular clasts of variable lithologies including "micaceous hornfelses", ophites and poorly serpentinized lherzolites (Fig. 3(3), (4)). The ultramafic clasts are more abundant close to the contact with the Lherz body. The entire outcrop is calcite-rich.

Although we could not observe the exact exposures described and sampled by Monchoux (1970, 1972a, 1972b), our field observations, even before any microscopic analysis, clearly match his description, in particular:

- the high diversity of the clastic layers components with frequent mixing of light-coloured material and ultramafic material;
- at site 2, a progressive transition from the sapphirine-bearing rocks to the pure marble breccias and microbreccias that dominantly form the overlying Lherz breccia. This transition is depicted by the white dotted line 1 in Figure 3(1).

Our sixteen samples allow to recover the diversity of types described by Monchoux (1970, 1972a, 1972b). Eleven samples were collected at site 1 (BCOR 71, BCOR 72, BCOR 73, LHZ 49, LHZ 7a, Momo 1, Momo 2, Momo 2a, Momo 2b, Momo 5 and Momo 6). Five samples were collected at site 2 (BCOR 67b, BCOR 68a, BCOR 68b, LHZ 114a and NR 94). Given the thorough mineralogical studies carried out on the same material by Monchoux (1970,1972a, 1972b) and by Abraham et al. (1977), we rather focus on textures, complementary mineral compositions and mineral inclusion patterns that could give clues as to the nature and origin of this uncommon material.

Thin sections were prepared for each sample for microscopic observation and electron microprobe (EMP) analyses. The latter were performed in the French Research 
Table 1. Main features of the different rock-types which constitute the sample collection. Simplified sketches are provided for each rock-type, taking into account their main features. Different colours indicate different mineral species. Abbreviations from Whitney and Evans (2010).

\begin{tabular}{|c|c|c|c|}
\hline & Type I & Type II & Type III \\
\hline Monomineralic clasts & Absence & Ultradominant & Ultradominant \\
\hline Polymineralic clasts & Presence & Very scarce & Very scarce \\
\hline Calcite in the cement & Absence & Presence & Absence \\
\hline Protoliths & $\begin{array}{l}\text { - Micaceous hornfels } \\
\text { Intermediate facies micaceous } \\
\text { hornfels/marbles }\end{array}$ & $\begin{array}{l}\text { One or serveral unknown } \\
\text { protoliths producing the SBMS }\end{array}$ & $\begin{array}{l}\text { Ultramafic rocks } \\
\text { Palaeozoic basement rocks } \\
\text {. Intrusives } \\
\text { - Micaceous hornfels } \\
\text { Sapphirine-bearing rocks }\end{array}$ \\
\hline \multicolumn{4}{|c|}{ Sampling location } \\
\hline \multirow{4}{*}{ Site 1} & & $*$ & $*$ \\
\hline & & & $*$ \\
\hline & & & $*$ \\
\hline & $*$ & & \\
\hline Site 2 & & $*$ & \\
\hline Simplified sketch & $\begin{array}{l}\text { Phl+Di } \\
+ \text { Tur }\end{array}$ & Calcite cement & 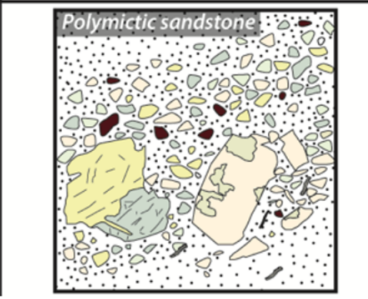 \\
\hline
\end{tabular}

Institute for Exploitation of the Sea (Ifremer) in Plouzané (Brest, France) using a CAMECA SX100 instrument, equipped with five spectrometers and a full set of analysing crystals. Further imaging and analyses in energy-dispersive mode (EDS) were carried out on five samples using a Zeiss ¿igma $^{\text {TM }}$ field-emission-gun scanning electron microscope equipped with a large-area $\left(50 \mathrm{~mm}^{2}\right)$ EDS silicon drift detector, X-Max Oxford Instruments, at ENS Paris. Raman analyses for phase characterization in sample BCOR 72 were obtained using the Renishaw inVia spectrometer at ENS Paris, with a 514.5-nm argon laser focused through a DMLM Leica microscope. The signal was filtered by edge filters, dispersed by a 1200 or 1800 grooves $/ \mathrm{mm}$ grating and analysed with a Peltier cooled RENCAM CCD detector, using Si as calibration standard.

In addition, laser ablation inductively coupled mass spectrometry (LA-ICP-MS) U-Pb dating was performed on some rutile grains using an ESI NWR193UC Excimer Laser coupled to an Agilent quadripole 7700x ICP-MS available at Géosciences Rennes. Information regarding the analytical procedures can be found in the Supplementary Material 1.

\section{Results}

A precise description of each studied sample is provided in the Supplementary Material 2.

\subsection{General petrography}

Three main types of samples can be distinguished on the basis of their mineralogical compositions (Tab. 1):
- Type I was collected in coarse breccias of Layer D at site 1 and corresponds to portions of polymineralic clasts (Fig. 2);

- Type II was collected in Layer A at site 1 and at site 2. It corresponds to microbreccias with a calcitic cement and made of either $100 \%$ of monomineralic clasts or scarce polymineralic clasts associated with predominant monomineralic clasts;

- Type III was collected in Layers A, B and C at site 1 and corresponds to microbreccias devoid of any calcitic cement and made of either $100 \%$ of monomineralic clasts or of scarce polymineralic clasts associated with predominant monomineralic clasts.

Type I samples are very homogeneous (Tab. 2, Fig. 4). Samples BCOR 71, Momo 2 and Momo 6 are made of scapolite (with anorthite, phlogopite, tourmaline and apatite inclusions), phlogopite, diopside, tourmaline and scarce epidote and zoisite. They correspond to clasts of the emblematic Pyrenean "micaceous hornfelses" (Lacroix, 1894), i.e. metamorphic Upper Triassic to Lower Jurassic sediments and evaporites. Sample Momo 5 is made of scapolite, diopside, anorthite, phlogopite, potassian hastingsite, tourmaline and calcite and thus corresponds to some intermediate facies between the "micaceous hornfelses" and the surrounding marbles (Ravier and Thiébaut, 1982).

Type II samples are also rather homogeneous (Fig. 5). Six of the eight samples include sapphirine crystals, and the other two samples include minerals that commonly occur together with sapphirine in our samples (Tab. 2). The complete suite in Type II samples is: sapphirine (with Cl-rich apatite and rutile 
Table 2. Mineralogy of the sample collection. Abbreviations from Whitney and Evans (2010).

\begin{tabular}{|c|c|c|c|c|c|c|c|}
\hline & Site & $\begin{array}{l}\text { Layer type } \\
\text { (at site 1) }\end{array}$ & Sample & Cement & Monomineralic clasts & Polymineralic clasts & Inclusions in minerals \\
\hline Type I & Site 1 & Layer D & $\begin{array}{l}\text { BCOR 71 } \\
\text { Momo 2 } \\
\text { Momo } 5 \\
\text { Momo 6 } \\
\end{array}$ & None & None & $\begin{array}{l}\text { Di, Phl, Scp, Ep, Tur } \\
\text { Di, Phl, Scp, Tur } \\
\text { Di, Phl, Scp, An, K-Hs, Tur, Cal } \\
\text { Di, Phl, Scp, An, Zo }\end{array}$ & $\begin{array}{l}\mathrm{Phl}, \text { Tur, Cl-Ap, An in Scp } \\
\mathrm{Phl}, \text { Tur, Cl-Ap, An in Scp }\end{array}$ \\
\hline & Site 1 & Layer A & $\begin{array}{l}\text { Momo 2a } \\
\text { Momo 2b } \\
\text { LHZ 7a }\end{array}$ & & $\begin{array}{l}\text { Ged, Prg, Vrm } \\
\text { Al-Spl, Ap, Ged, Mg-Hb, Spr, Vrm } \\
\text { Al-Spl, Ca-Amp (Ts?), Ath, Rt, Spr, Tur, Vrm }\end{array}$ & $\begin{array}{l}\text { None } \\
\text { None } \\
\text { None }\end{array}$ & \\
\hline Type II & Site 2 & & $\begin{array}{l}\text { LHZ 114a } \\
\text { BCOR 67b } \\
\text { BCOR 68a } \\
\text { BCOR 68b } \\
\text { NR } 94\end{array}$ & Cal & $\begin{array}{l}\text { Di, Al-En, Ged, Prg, Spr, Srp, Vrm } \\
\text { Al-Spl, Cl-Ap, Rt, Spr, Sme, Vrm } \\
\text { Ath-Ged, Rt, Spr, Sme, Vrm } \\
\text { Ath-Ged, Rt, Spr, Sme, Vrm } \\
\text { Al-En, Al-Spl, Ap, Prg, Rt, Vrm }\end{array}$ & $\begin{array}{l}\text { None } \\
\text { Al-Spl, Spr } \\
\text { Ath, Spr } \\
\text { Ath, Vrm } \\
\text { Spr, Vrm } \\
\text { Ath, Spr, Vrm } \\
\text { Spr, Vrm } \\
\text { Ath, Spr, Vrm } \\
\text { None }\end{array}$ & $\begin{array}{l}\text { Ap in Spr } \\
\text { Rt in Ath-Ged } \\
\text { Cl-Ap, Rt in Spr } \\
\\
\text { Rt in Ath-Ged } \\
\text { Cl-Ap, Rt in Spr } \\
\text { Anh, Ap, Clc, Zrn in Al-En } \\
\text { Zrn, Cl-Ap in Prg }\end{array}$ \\
\hline \multirow{3}{*}{ Type III } & \multirow{3}{*}{ Site 1} & Layer A & BCOR 72 & \multirow{3}{*}{ None } & Al-En, Di, Ged, Krn, Prg, Rt, Spr, Tur, Vrm, White mica & $\begin{array}{l}\text { Ged, Spr } \\
\text { Prg, Vrm }\end{array}$ & $\begin{array}{l}\text { Rt in Ged } \\
\text { Rt, Ap, Anh in Krn } \\
\text { Rt in Prg }\end{array}$ \\
\hline & & Layer B & $\begin{array}{l}\text { Momo } 1 \\
\text { LHZ 49 }\end{array}$ & & $\begin{array}{l}\text { Chl, Cpx, En, Cr-Hc, Mg-Hb, Ms, Phl, Pl, Qz } \\
\text { Chl, Di, En, Hc, Cr-Hc, Ol, Ti-Prg, Qz }\end{array}$ & $\begin{array}{l}\text { En, Ol }( \pm \mathrm{Cr}-\mathrm{Hc}) \\
\mathrm{Di}, \mathrm{En} \\
\mathrm{Mg}-\mathrm{Hb}, \mathrm{Pl} \pm \mathrm{Cpx} \\
\text { En, Ol, Pl } \\
\mathrm{Ms}, \mathrm{Phl}, \mathrm{Qz} \\
\text { None }\end{array}$ & Green $\mathrm{Hb}, \mathrm{Ap}$ in $\mathrm{Pl}$ \\
\hline & & Layer C & BCOR 73 & & Cpx, Prg, Rt, Scp, Green Spl, Tur, Vrm & Scp, Cpx, Vrm & \\
\hline
\end{tabular}

inclusions), enstatite (with anhydrite, F- and Cl-rich apatite, clinochlore and zircon inclusions), aluminous spinel, $\mathrm{Mg}$ amphiboles (anthophyllite-gedrite solid solution with rutile inclusions), Ca-amphiboles (pargasite with F- and Cl-rich apatite, clinochlore and zircon inclusions; tschermakite), tourmaline, rutile, vermiculite and smectite. The scarce polymineralic clasts are made of sapphirine and $\mathrm{Mg}$ amphibole of the gedrite-anthophyllite series, of sapphirine and aluminous spinel, of anthophyllite and vermiculite, of sapphirine and vermiculite, or of sapphirine, vermiculite and anthophyllite (Tab. 2). A striking feature in these samples is the abundance of kinked vermiculite with open cleavages and ponytail edges (Fig. 5(3)). These features suggest that vermiculite derives from the transformation of a former phyllite, likely phlogopite or aspidolite. Monomineralic and polymineralic clasts are all angular, except vermiculite.

Type III samples are far more heterogeneous in composition (Tab. 2):

- sample BCOR 72 is composed of an accumulation of millimetric to plurimillimetric isolated crystals, dominantly vermiculite and amphiboles with, in order of decreasing abundance: gedrite, pargasite, vermiculite, aluminous enstatite, kornerupine, sapphirine, diopside, tourmaline, rutile and white mica (Tab. 2). Very scarce polymineralic clasts are observed (Fig. 6(1)). One millimetric kornerupine crystal shows a subhedral shape (Fig. 6(2)). A very finegrained matrix composed of the previously listed minerals and devoid of any calcite can be observed locally;

- sample Momo 1 also appears as a friable orange-brown sandstone. It includes angular monomineralic clasts and subangular to rounded polymineralic clasts (Fig. 6(3) and (4)). Isolated detrital minerals include: magnesio-hornblende, enstatite, chromian hercynite, phlogopite, muscovite, clinopyroxene, quartz, chlorite and several types of plagioclase (An18-58). Polymineralic clasts include: unserpentinized (Fig. 6(3)) and serpentinized ultramafic rocks, meta-ophite (Fig. 6(4)), as well as one clast of granitic gneiss. A single clast composed of olivine, plagioclase (An56.9-58.1) and enstatite was also observed. This clast is reminiscent of rocks that are known in the Aulus Basin, namely a Cretaceous alkaline enstatite-gabbro (Les Plagnaux gabbro; Montigny et al., 1986; Ternet et al., 1997) or the cumulate portion of a Triassic ophitic intrusion (Azambre et al., 1987);

- sample LHZ 49 is an orange-brown fine-grained sandstone exclusively made of angular, submillimetric monomineralic clasts (Fig. 6(5)) from a dominant ultramafic protolith. Clasts include: olivine (Fo89.9-91.0), diopside, enstatite, titanian pargasite, hercynite, chromian hercynite, chlorite and minor quartz (Tab. 2);

- sample BCOR 73 is a yellowish phyllite-rich sandstone which contains a single centimetric subrounded greenish polymineralic clast (Fig. 6(6)). The sandstone is composed of angular monomineralic grains of various nature (in decreasing order of abundance): vermiculite, pargasite, clinopyroxene, scapolite, a green spinel, rutile and tourmaline (Tab. 2). The centimetric greenish subrounded clast derives from a scapolitized amphibolite with clinopyroxene and some vermiculite. This mineral assemblage derives from a " micaceous hornfels" (Lacroix, 1894; Ravier and Thiébaut, 1982), in which primary phlogopite or aspidolite was transformed into vermiculite. This clast is surrounded by vermiculite, oriented roughly parallel to the clast border (Fig. 6(6)). 

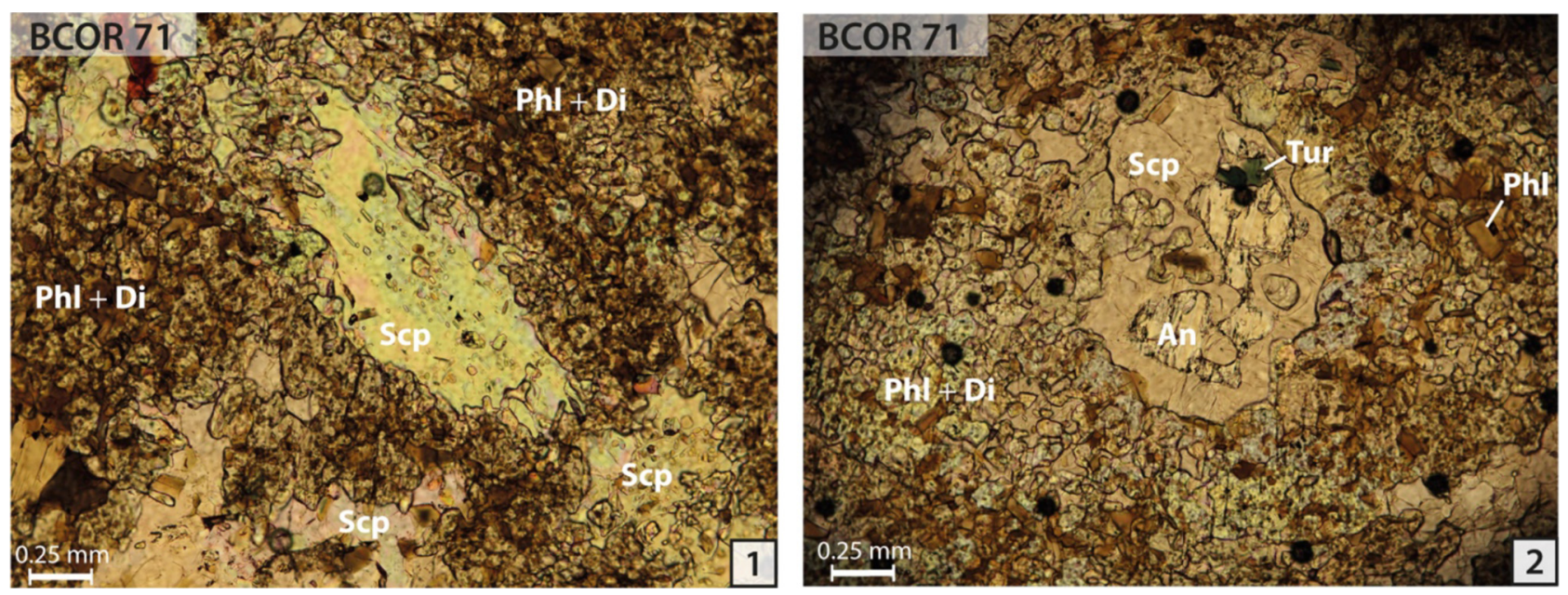

Fig. 4. Thin-section micrographs showing the main features of Type I samples: (1) "micaceous hornfels" clast. Note the poikiloblastic texture of the central scapolite, with numerous inclusions (plane-polarized light; sample BCOR 71); (2) "Micaceous hornfels" clast. Note the tourmaline and anorthite inclusions in the central scapolite (plane-polarized light; sample BCOR 71). Abbreviations from Whitney and Evans (2010).

\subsection{Textural analysis}

The numerous mineral species that compose the studied samples are all represented by angular and broken monomineralic clasts that obviously derive from a collection of various rock-types (Figs. 4-6, Tab. 2). In most cases, these clasts are submillimetric fragments of crystals that are disconnected from their original protolith. We also observe larger isolated crystals, millimetric to plurimillimetric in size (centimetric in rare instances, as in samples BCOR 68a and NR 94), of the same species as the submillimetric clasts of the matrix. The largest clasts may be surrounded by submillimetric debris of the same mineral species (Fig. 7). Most of the polymineralic clasts are millimetric to plurimillimetric in size. They are fractured with irregular borders (except in sample Momo 1). In most samples of types II and III which include both monomineralic and polymineralic clasts, the mineral species of the monomineralic clasts are the same as those forming the polymineralic clasts.

In seven samples of types II and III, a layering is observable macroscopically (samples Momo 1, Momo $2 \mathrm{~b}$ and NR 94) or microscopically (samples LHZ 49 and LHZ 7a, BCOR 72 and BCOR 73 (Figs. 8 and 9, see also Fig. 6(5)). The layers are usually characterized by the accumulation of one or two specific minerals. Representative examples are samples BCOR 72 (Fig. 9) and BCOR 73 which both display overabundances of amphiboles and vermiculite. In these cases, the layering is also outlined by the alignment of the planar minerals (in particular vermiculites). In some examples, layering is locally interrupted against polymineralic clasts, the borders of which are coated by planar minerals (e.g., sample BCOR 73, Fig. 6(6)). In sample Momo 1, layering results from the accumulation of polymineralic clasts of different compositions (Fig. 8(2)). In addition, each layer may exhibit a grain-size sorting, as also observed in sample NR 94 (Fig. 8(1)).

\subsection{Definition of the sapphirine-bearing mineral suite (SBMS)}

The petrographic study of the sixteen thin sections of sapphirine-bearing rocks reveals that some polymineralic clasts or isolated minerals derive from well-known protoliths such as ultramafic rocks, meta-ophites, micaceous hornfels and, rarely, Paleozoic basement rocks. This is the case for our Type I and part of our Type III, as reported above. Nevertheless, a large portion of the sapphirine-bearing clastic suite is composed of mono- and polymineralic debris that derive from unknown protolith(s). This is the case for Type II and part of Type III samples. The complete mineral suite in these samples is: sapphirine + enstatite + aluminous spinel $+\mathrm{Mg}$ amphiboles + Ca-amphiboles + kornerupine + accessory minerals (apatite, diopside, rutile, serpentine, smectite, tourmaline, vermiculite and a white mica; Tab. 2). The high recurrence of these minerals found in association with sapphirine in our sample collection leads us to define a "sapphirine-bearing mineral suite", referred to as SBMS.

As reported above, most of the clasts observed in the sapphirine-bearing sandstones are monomineralic and isolated. However, rare clasts of polymineralic aggregates exhibiting textural equilibrium are observed in some samples. They are made of sapphirine and Mg-amphibole, of sapphirine and aluminous spinel, of anthophyllite and vermiculite, of sapphirine and vermiculite, or of sapphirine, vermiculite and anthophyllite (Tab. 2). The most frequent associations involve sapphirine and Mg-amphibole of the gedrite-anthophyllite series. These minerals are commonly intergrown, which suggests that they crystallized simultaneously (Fig. 5(1), (5), (6) and Fig. 6(1)).

Finally, we point out that the assemblages represented by the SBMS derive from metamorphic source-rocks that have never been described so far in the Lherz area. In the following, our aim is to characterize these metamorphic source-rocks. 

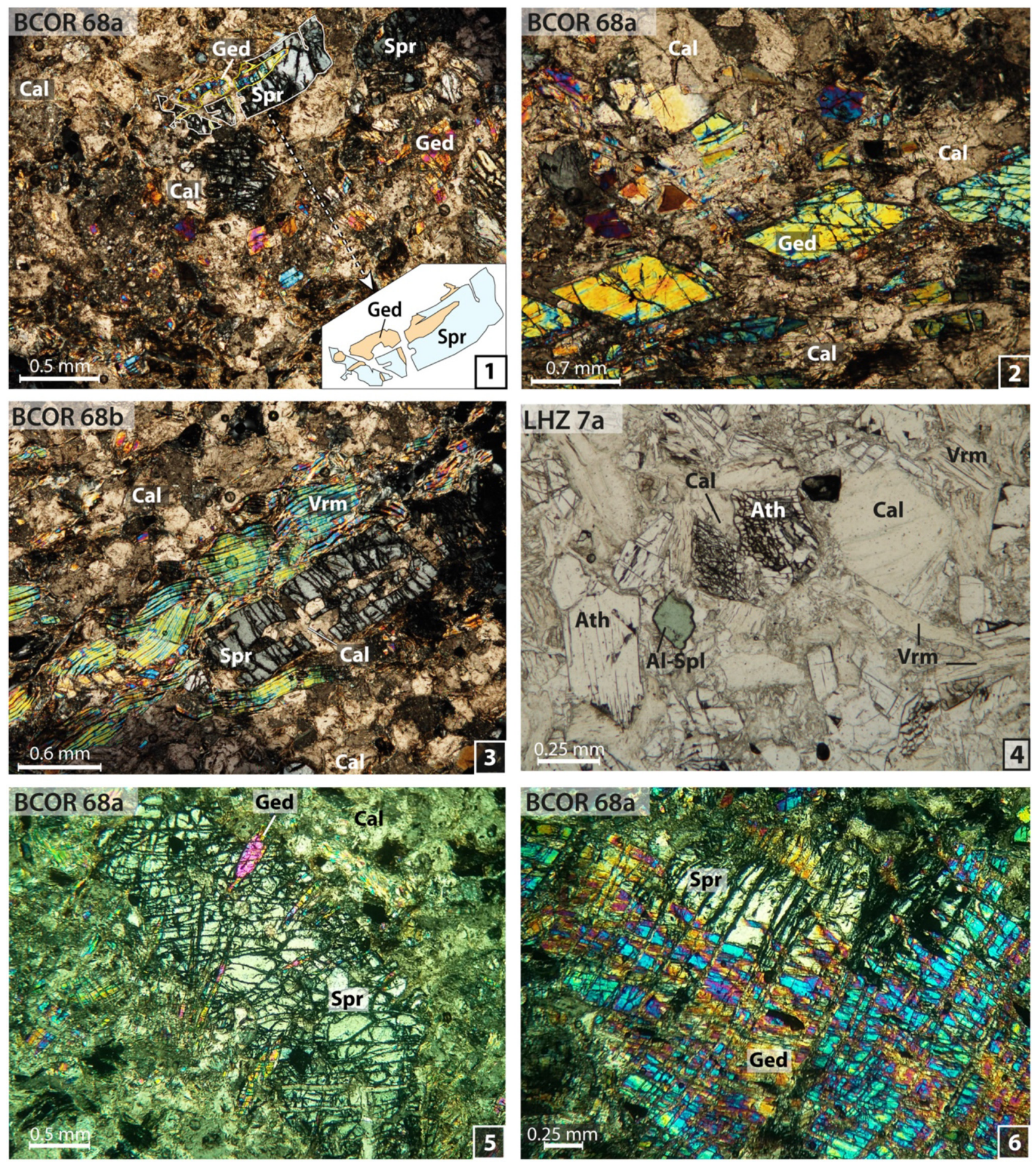

Fig. 5. Representative micrographs of Type II samples: (1) representative example of the sapphirine-bearing microbreccias (cross-polarized light; sample BCOR 68a). Note the dominant highly fractured monomineralic clasts and the calcitic cement. One fractured polymineralic clast (sapphirine + gedrite) appears in the upper central part of the picture (redrawn in the inset); (2) plurimillimetric monomineralic clast of gedrite fragmented with very few displacements between the debris (cross-polarized light; sample BCOR 68a); (3) sapphirine crystal showing corrosion gulfs infilled with calcite, surrounded by kinked vermiculite crystals displaying open cleavages (cross-polarized light; sample BCOR 68b); (4) a highly-fractured subhedral anthophyllite crystal, with calcite infill (plane-polarized light; sample BCOR 72); (5) and (6) polymineralic clasts showing the intergrowth relationships between sapphirine and gedrite (cross-polarized light; sample BCOR 68a). Abbreviations from Whitney and Evans (2010). 

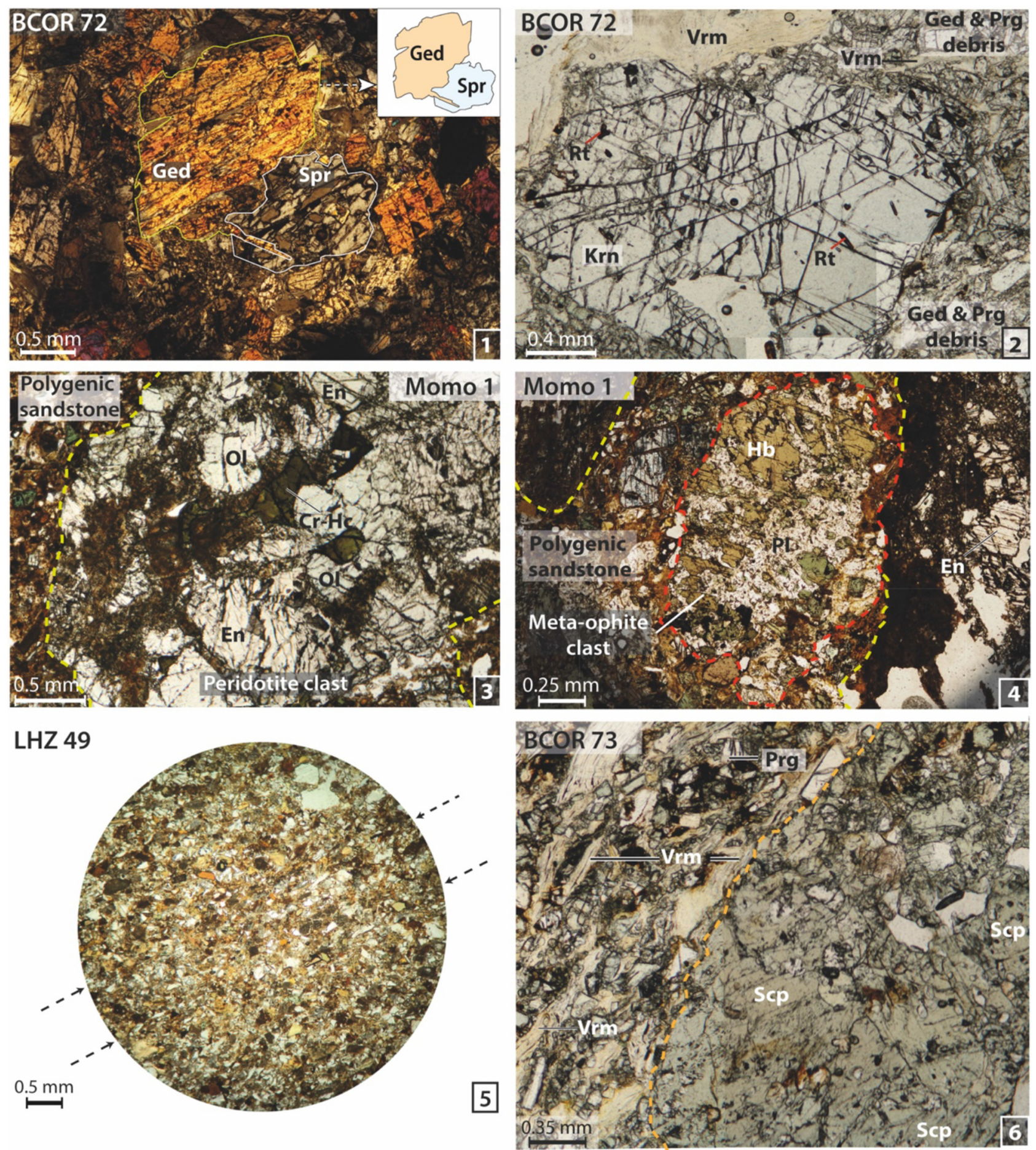

Fig. 6. Representative micrographs of Type III samples: (1) polymineralic clast of sapphirine + gedrite showing textural equilibrium between the two phases (redrawn in the inset; cross-polarized light; sample BCOR 72). Areas appearing in brown in the sapphirine crystal correspond to voids generated when the thin section was prepared; (2) millimetric subhedral kornerupine crystal displaying parallel-oriented rutile inclusions (plane-polarized light; sample BCOR 72); (3) peridotite clast. Yellow dotted lines underline the limits of the polymineralic clast (plane-polarized light; sample Momo 1); (4) meta-ophite clast underlined by a red dotted line. Two ultramafic clasts are underlined by yellow dotted lines (planepolarized light; sample Momo 1); (5) polymictic sandstone exclusively made of monomineralic clasts. A coarse bedding is underlined by planar minerals (black dotted arrows parallel to the bedding; plane-polarized light; sample LHZ 49); (6) polymineralic clast of scapolitite (underlined by an orange dotted line) enclosed in a sandstone made of monomineralic clasts. Note the orientation of the vermiculite flakes, parallel to the borders of the scapolitite clast (plane-polarized light; sample BCOR 73). Abbreviations from Whitney and Evans (2010). 

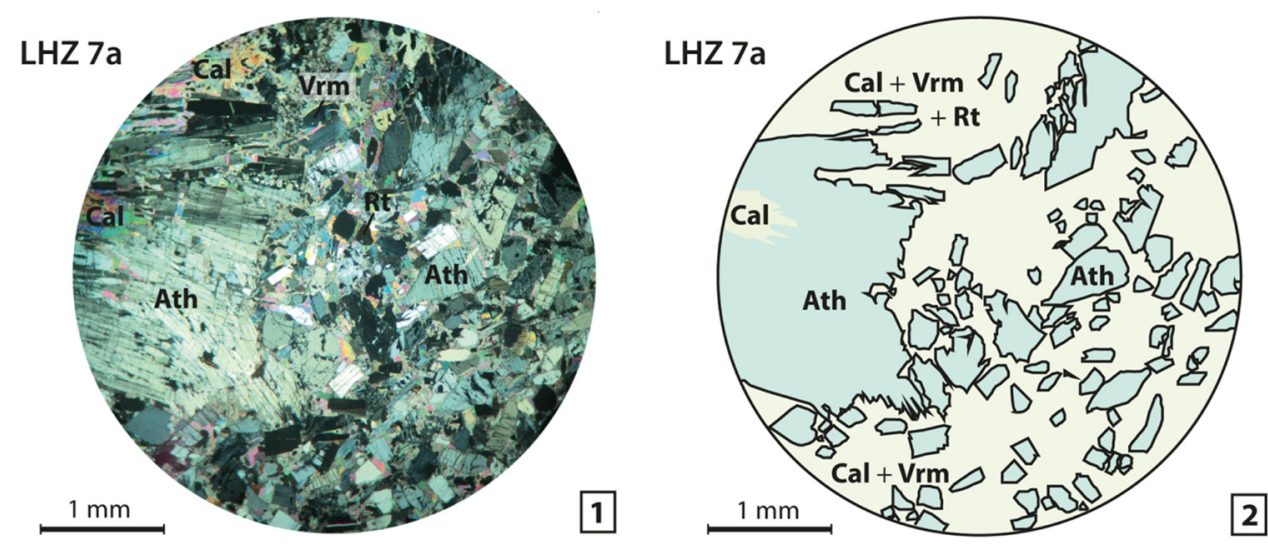

Fig. 7. Evidence of mineral fragmentation: (1) highly fractured plurimillimetric crystal of anthophyllite (left side) disaggregated into small angular pieces that fed the microbreccia (cross-polarized light; sample LHZ 7a); (2) line drawing of (1) highlighting the fragmentation of anthophyllite. Abbreviations from Whitney and Evans (2010).

\subsection{Mineral chemistry of the SBMS}

Representative analyses of the main phases forming the SBMS are given in Table 3. The chemistry of some minerals of the SBMS uncommonly observed in the region is detailed in the following:

- sapphirine occurs in seven samples (Tab. 2, Fig. 5(1), (3), (5), (6), Fig. 6(1) and Fig. 10(1)). In the microbreccias, it appears as up to millimetre-size (LHZ 7a), pale blue to deep blue subhedral crystals, always fractured and commonly corroded. The corrosion gulfs are filled by calcite in Type II samples (Fig. 5(3) and Fig. 10(1)). Microprobe analyses show that the sapphirine-bearing clasts display high $\mathrm{Mg}$ content $\left(\mathrm{X}_{\mathrm{Mg}}=\mathrm{Mg} /\left(\mathrm{Mg}+\mathrm{Fe}_{\text {total }}\right)=0.91-0.92\right)$, except in LHZ 7a for which $X_{\mathrm{Mg}}$ values of 0.83-0.86 may reflect a higher proportion of ferric iron, as suggested by the analysis of spinel. With 1.58(4) Si per formula unit (pfu), sapphirine is close to the classical 7:9:3 (Mg,Fe)O: $\mathrm{Al}_{2} \mathrm{O}_{3}: \mathrm{SiO}_{2}$ composition (e.g., Podlesskii, 2010). It is nearly devoid of $\mathrm{Cr}_{2} \mathrm{O}_{3}(<0.06 \mathrm{wt} \%)$ and $\mathrm{NiO}(<0.02 \mathrm{wt} \%)$;

- kornerupine occurs in sample BCOR 72 as a millimetric prismatic subhedral crystal and as fragments with no relationship to each other (Fig. 6(2) and Fig. 10(2)). It contains $2.3 \mathrm{wt} \% \quad \mathrm{~B}_{2} \mathrm{O}_{3}$ according to a wet chemical analysis (Monchoux, 1972a), 3.0 wt\% according to EMP analysis in Table 3 . It is also characterized by a high $\mathrm{X}_{\mathrm{Mg}}$ value $(0.93)$ and low $\mathrm{Cr}_{2} \mathrm{O}_{3}(<0.04 \mathrm{wt} \%)$ and $\mathrm{NiO}$ $(<0.08 \mathrm{wt} \%)$ contents;

- aluminous enstatite occurs as pale blue crystals in three samples (samples LHZ 114a, NR 94, BCOR 72; Tab. 2). It shows a consistent $\mathrm{X}_{\mathrm{Mg}}$ value of $0.90(1), \mathrm{Al}_{2} \mathrm{O}_{3}$ contents from 1.89 to $3.48 \mathrm{wt} \%$, with an average of $2.5 \mathrm{wt} \%$, i.e. $5 \mathrm{~mol} \% \mathrm{Mg}$-Tschermak $\left(=\mathrm{MgAl}_{2} \mathrm{SiO}_{6}\right)$ component. This is among the lowest $\mathrm{Al}$ contents in enstatite reported from sapphirine-bearing rocks. The $\mathrm{TiO}_{2}(<0.11 \mathrm{wt} \%), \mathrm{Na}_{2} \mathrm{O}$ $(<0.19 \mathrm{wt} \%)$ and $\mathrm{Cr}_{2} \mathrm{O}_{3}(<0.5 \mathrm{wt} \%$, mostly $<0.3 \mathrm{wt} \%)$ contents are not distinctive from enstatite from the Lherz lherzolite (Le Roux et al., 2007, her corrected Tab. 2), but the low $\mathrm{CaO}$ contents are distinctive $(<0.21 \mathrm{wt} \%$, versus 0.3 to $1.3 \mathrm{wt} \%$ in lherzolite);
- aluminous spinel occurs as blue fragments in mono- or polymineralic clasts (Tab. 2, Fig. 5(4)); unlike the clasts of brown or green spinel, it cannot be traced back to common rock-types of the area, either basement or ultramafic bodies. The low $\mathrm{Cr}_{2} \mathrm{O}_{3}(<0.1 \mathrm{wt} \%)$ and $\mathrm{Fe}_{2} \mathrm{O}_{3}$ contents $\left(<0.05 \mathrm{Fe}^{3+}\right.$ pfu $)$ as well as high $\mathrm{Al}$ and high $\mathrm{X}_{\mathrm{Mg}}(>0.8)$ are distinctive.

The above four mineral species are highly magnesian, as are most of the other species of the SBMS. Indeed, gedrite, anthophyllite, pargasite, vermiculite and tourmaline all have $\mathrm{MgO} \pm \mathrm{Al}_{2} \mathrm{O}_{3} \pm \mathrm{SiO}_{2} \quad\left( \pm \mathrm{B}_{2} \mathrm{O}_{3}\right)$ as their main constituents (Tab. 3).

Sapphirine crystals in samples BCOR 67b, BCOR 68a and BCOR 68b display apatite inclusions (Tab. 2, Fig. 10(1)) that are extremely rich in $\mathrm{Cl}(4.4-4.7 \mathrm{wt} \%$, Tab. 4), close to chlorapatite end-member. Kornerupine crystals bear Cl-rich apatite and anhydrite inclusions (sample BCOR 72; Fig. 10 (2)). Aluminous enstatite bears inclusions of Cl-rich fluorapatite $(1.93 \mathrm{wt} \% \mathrm{Cl}$ and $2.02 \mathrm{wt} \% \mathrm{~F}$ on average) and of $\mathrm{Sr}-$ bearing anhydrite $(0.42 \mathrm{wt} \% \mathrm{SrO}$ on average) which may also be associated (Fig. 10(3)), and of clinochlore (sample NR 94; Tabs. 2 and 4; Fig. 10(4)). Ca-amphibole crystals also display rare apatite inclusions (sample NR 94).

\subsection{U-Pb dating of rutile in samples BCOR 68a and $\mathrm{b}$}

Since the Pyrenees experienced three metamorphic episodes (see section 2.1 above), we performed a geochronological study on the only mineral found to be suitable for geochronological dating: rutile (Tab. 2). U-Pb geochronology of rutile was conducted in-context in samples BCOR 68a and b in order to constrain the age of the SBMS. Given their very similar content and sampling location, we consider that these two samples derive from a same (and still unknown) protolith and experienced the same geological processes (Tab. 2).

Twenty-six analyses were acquired on ten rutile grains (100 to $200 \mu \mathrm{m}$ in length) during two analytical sessions (Tab. 5). All analyses were acquired on monomineralic rutile clasts, except three analyses which were performed on a similar rutile inclusion located within a sapphirine crystal clast (S-301018a-1, 

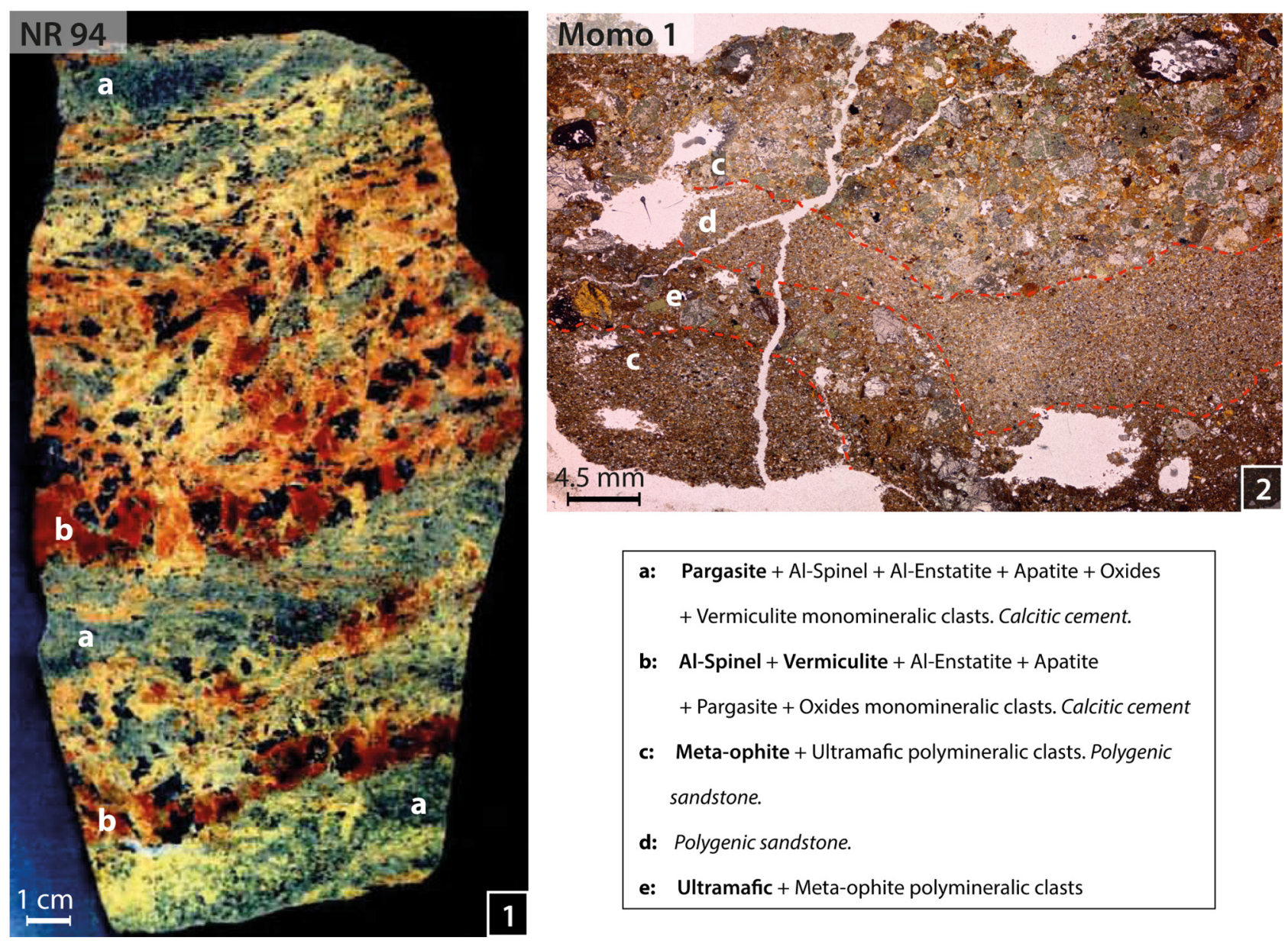

\begin{tabular}{|l} 
a: $\quad$ Pargasite + Al-Spinel + Al-Enstatite + Apatite + Oxides \\
+ Vermiculite monomineralic clasts. Calcitic cement. \\
b: Al-Spinel + Vermiculite + Al-Enstatite + Apatite \\
+ Pargasite + Oxides monomineralic clasts. Calcitic cement \\
c: Meta-ophite + Ultramafic polymineralic clasts. Polygenic \\
sandstone. \\
d: Polygenic sandstone. \\
e: Ultramafic + Meta-ophite polymineralic clasts
\end{tabular}

Fig. 8. Evidence of layering at macro-scale. The mineral content of each layer is given in the inset. Dominant elements in each layer are shown in bold: (1) photograph of NR 94 sample. Layering is defined by alternating bluish (a) and yellow-orange layers (b), characterized by various grain sizes and by slightly different mineral compositions (see Supplementary material SM2 for a complete description); (2) thin section photograph of sample Momo 1. A layering is underlined by red dotted lines.

S-301018a-2, S-301018a-3; BSE images are provided in Supplementary Material 3). Whatever their location, analyses show variable $\mathrm{U}(58-164 \mathrm{ppm})$ and $\mathrm{Pb}(1-441 \mathrm{ppm})$ contents with variable amounts of common $\mathrm{Pb}(f 206 \%$ between 0 and $2.3 \%$ ) (Tab. 5). In a Tera-Wasserburg diagram (Fig. 11), they all plot in a concordant to discordant position (depending on the amount of common $\mathrm{Pb}$ ) and define a well-constrained lower intercept date of $98.6 \pm 1.2 \mathrm{Ma}(\mathrm{MSWD}=1.6)$. This date is equivalent within error to the ${ }^{207} \mathrm{~Pb}$-corrected date (calculated using Stacey and Kramers (1975) terrestrial $\mathrm{Pb}$ evolution model calculated at $100 \mathrm{Ma}$ ) of $98.9 \pm 0.7 \mathrm{Ma}$ $(\mathrm{MSWD}=1.4, n=26)$.

\section{Discussion : origin of the sapphirine- bearing rocks}

\subsection{Evidence for a tectono-sedimentary origin}

The petrological descriptions of the sixteen samples collected at sites 1 and 2 show that the sapphirine-bearing sandstones and breccia formation is an assemblage of beds of various mineralogical composition and grain size with thicknesses varying from some millimetres to some decimetres.
In section 4.2 , we describe microbreccia and sandstone samples made of the accumulation of highly fragmented minerals and polymineralic clasts. We show that in most samples, monomineralic clasts exhibit angular shapes, sometimes with little displacement between fragments, and are of the same species as minerals forming the polymineralic clasts. This reinforces the hypothesis of an in-situ disaggregation of the largest clasts to form the submillimetric monomineralic clasts. However, in two samples some monomineralic submillimetric clasts do not have their polymineralic counterpart (e.g., quartz in sample Momo 1; pargasite, rutile and green spinel in sample BCOR 73), which implies clast mixing at a scale larger than the hand specimen size. Our textural analysis also reveals a layering often defined by the accumulation of one or two specific minerals or polymineralic clasts in seven samples, as well as grain-size sorting at microscopic and macroscopic scales. Those samples which concentrate only few mineralogical species do not correspond to any classical protolith of metamorphic or plutonic origin and can be regarded as placer deposits.

These observations collectively imply that the sapphirinebearing sandstones and breccias accumulated through sedimentary processes in a context of active tectonics allowing for 

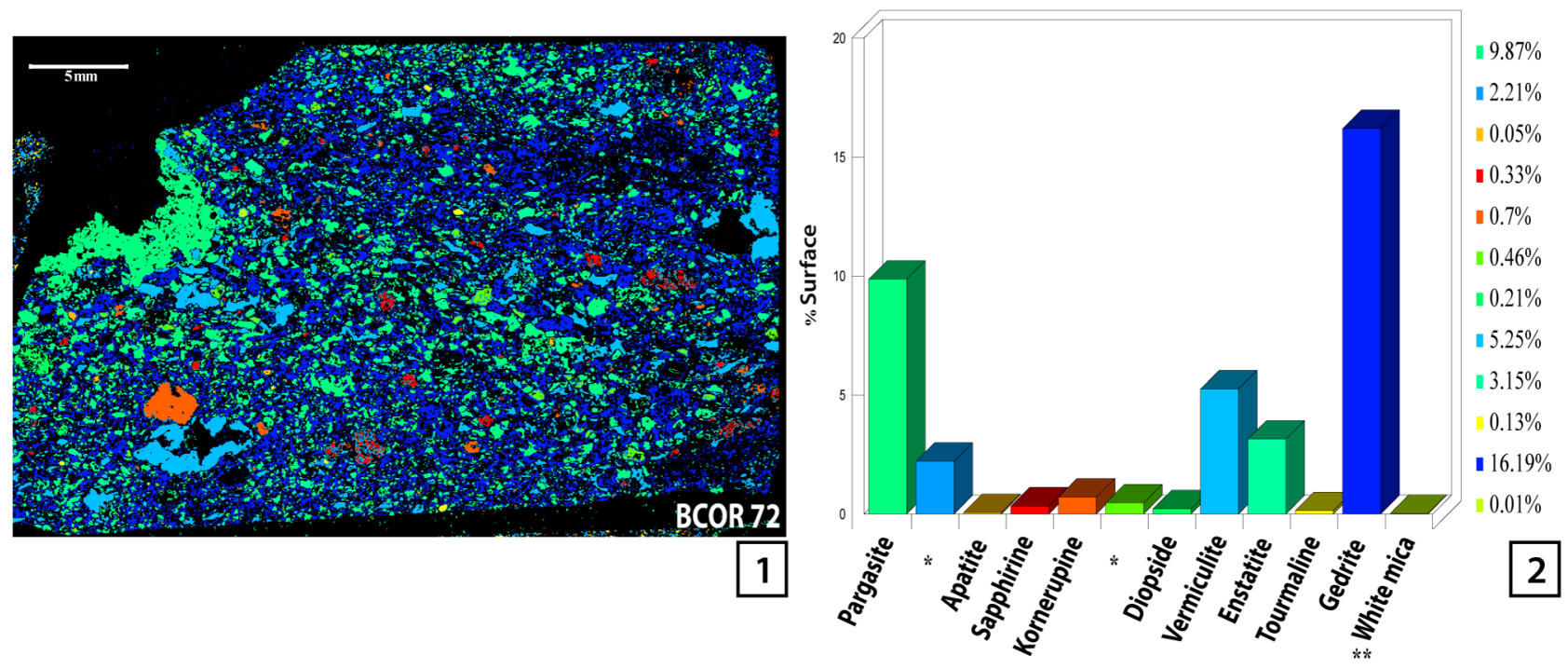

Fig. 9. Layering defined by overconcentration of minerals in BCOR 72 sample. 1) Phase map (EDS analysis, elemental mapping); 2) surface percentage of each mineral species. * Undetermined, possibly weathered phases. ${ }^{*}$ Not observed in thin section.

the brecciation of a variety of lithological assemblages. Identifying all the involved lithologies, especially the protolith(s) of the SBMS is thus necessary before any attempt at understanding the geodynamic setting in which those brecciation and mixing processes occurred.

\subsection{Deciphering the sources of the material reworked in the sapphirine-bearing rocks}

\subsubsection{Unequivocal sources}

Several sources can be unambiguously identified through the mineralogical composition of the studied microbreccia clasts, especially the polymineralic ones. These sources include:

- mantle rocks, either fresh or serpentinized, as shown by polymineralic clasts including forsterite, serpentine, enstatite, diopside, hercynite or chromian hercynite and by serpentine, hercynite or chromian hercynite isolated crystals;

- Upper Triassic to Lower Jurassic meta-ophites (Azambre et al., 1987) as shown by polymineralic clasts including magnesio-hornblende, diopside and plagioclase hosting abundant solid and fluid inclusions, and by isolated plagioclase crystals with the same inclusions;

- Upper Triassic to Lower Jurassic-deriving "micaceous hornfelses" (Lacroix, 1894; Ravier and Thiébaut, 1982) are identified through polymineralic clasts including scapolite, anorthite, diopside, phlogopite, tourmaline, epidote or apatite and through isolated tourmaline crystals;

- continental basement rocks, represented by one single polymineralic clast made of quartz, phlogopite and muscovite.

The conclusion from this first inventory is that, apart from lherzolites and very scarce basement rocks, the unequivocally identified protoliths that fed the sandstones and breccias derive from an Upper Triassic to Lower Jurassic sequence, which is composed of evaporitic sediments hosting ophites and is affected by the HT-LP Cretaceous metamorphic episode. No protolith containing the complete mineralogy of the SBMS exist in the vicinity of our study zone. The source(s) of the SBMS still have to be identified.

\subsubsection{Source(s) of the SBMS}

\subsubsection{Sapphirine-bearing rocks in the Pyrenees: a comparison}

The present location of the SBMS is the interface between the Lherz exhumed mantle and the Mesozoic marbles and breccias. A comparable situation is encountered for very similar rocks located $40 \mathrm{~km}$ East of Lherz, in the Bois de Fajou site (Monchoux, 1970; Fig. 1(1)). The latter author also mentioned panning concentrates containing euhedral sapphirine crystals from catchments in the Central Pyrenees, not far from lherzolite bodies (Fig. 2 in Monchoux, 1972a). This strengthens the idea of considering the sapphirine-bearing rocks as the lowermost levels of the Lherz breccia.

In the Pyrenees, sapphirine is also a component of mineral assemblages commonly involved in major contact zones between mantle and crust, formed under granulitic conditions. In that respect, sapphirine-bearing assemblages have been reported from both the Castillon North Pyrenean Massif and in Caussou, only $30 \mathrm{~km}$ away from the Lherz body (NPZ, Ariège, France; Fig. 1(1)). In the Castillon Massif, sapphirine was described in amphibolites and in corundum-bearing anorthosites that crop out in contact zones between mantle-derived peridotites and crustal kinzigites (Roux, 1977). These sapphirine-bearing amphibolites were interpreted as crustal rocks metamorphosed at the contact with lherzolites (Vielzeuf and Kornprobst, 1984). In Caussou, rare sapphirine has been reported from amphibole-rich peridotites (Conquéré, 1978).

The previously referenced settings do not yield proper images of the SBMS because:

- sapphirine crystals are anhedral in these examples;

- no boron-bearing mineral (tourmaline, kornerupine) nor mineral inclusion ( $\mathrm{Cl}$-and $\mathrm{F}$-rich apatite, tourmaline, anhydrite) 
Table 3. Representative analyses of the main phases of the SBMS. When several analyses are available for a mineral species, the average composition and the corresponding structural formula are given. For vermiculite and smectite, the structural formulae were not determined due to the great diversity of the microprobe analyses in our sample collection. Average values are calculated on the basis of: a) 12 analyses from four samples; b) 29 analyses from two samples; c) seven analyses from three samples; d) five analyses from two samples; e) nine analyses from four samples; f) 19 analyses from three samples; g) single analysis; h) three analyses from one sample; i) single analysis; j) five analyses from two samples; k) 46 analyses from six samples; 1) six analyses from two samples.

\begin{tabular}{|c|c|c|c|c|c|c|c|c|}
\hline & \multicolumn{2}{|c|}{ Sapphirine } & \multicolumn{2}{|c|}{ Enstatite } & \multicolumn{2}{|c|}{ Aluminous spinel } & \multicolumn{2}{|c|}{ Mg-amphibole (anthophyllite) } \\
\hline $\mathrm{SiO}_{2}$ & 13.37 & $12.79-13.7$ & 56.40 & $55.49-57.29$ & 0.02 & $0.00-0.06$ & 56.03 & $55.51-56.91$ \\
\hline $\mathrm{TiO}_{2}$ & 0.09 & $0.02-0.13$ & 0.05 & $0.00-0.11$ & 0.02 & $0.00-0.07$ & 0.13 & $0.08-0.18$ \\
\hline $\mathrm{Al}_{2} \mathrm{O}_{3}$ & 62.95 & $59.49-64.85$ & 2.51 & $1.89-3.48$ & 67.06 & $65.10-68.65$ & 4.93 & $4.90-5.25$ \\
\hline $\mathrm{CaO}$ & 0.04 & $0.00-0.06$ & - & - & 0.08 & $0.04-0.13$ & 0.00 & $0.00-0.01$ \\
\hline $\mathrm{MgO}$ & 19.44 & $18.90-19.81$ & 33.94 & $32.29-35.34$ & 22.33 & $20.78-23.45$ & 29.24 & $28.65-29.55$ \\
\hline $\mathrm{CaO}$ & 0.04 & $0.00-0.06$ & 0.14 & $0.05-0.21$ & 0.04 & $0.02-0.05$ & 0.59 & $0.44-0.73$ \\
\hline $\mathrm{Na}_{2} \mathrm{O}$ & 0.01 & $0.00-0.05$ & 0.04 & $0.00-0.19$ & 0.00 & $0.00-0.02$ & 0.47 & $0.38-0.58$ \\
\hline $\mathrm{K}_{2} \mathrm{O}$ & 0.01 & $0.00-0.02$ & 0.02 & $0.00-0.05$ & 0.00 & $0.00-0.01$ & 0.01 & $0.00-0.02$ \\
\hline $\mathrm{NiO}$ & 0.01 & $0.00-0.02$ & - & - & 0.00 & $0.00-0.01$ & 0.00 & $0.00-0.00$ \\
\hline
\end{tabular}

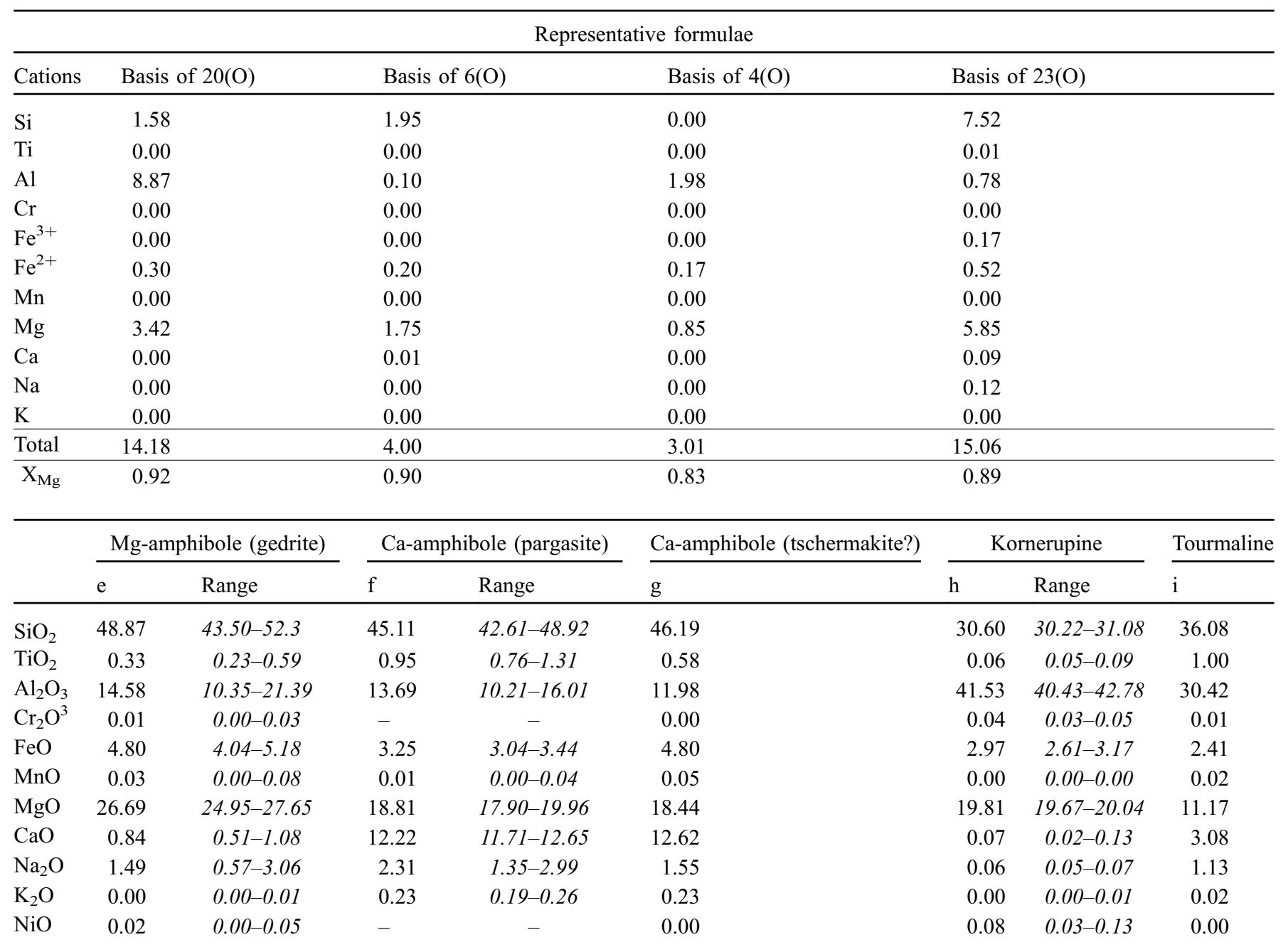


Table 3. (continued).

\begin{tabular}{|c|c|c|c|c|c|c|c|c|}
\hline & \multicolumn{2}{|c|}{ Mg-amphibole (gedrite) } & \multicolumn{2}{|c|}{ Ca-amphibole (pargasite) } & $\frac{\text { Ca-amphibole (tschermakite?) }}{\mathrm{g}}$ & \multicolumn{2}{|c|}{ Kornerupine } & $\frac{\text { Tourmaline }}{\mathrm{i}}$ \\
\hline $\mathrm{P}_{2} \mathrm{O}_{5}$ & 0.01 & $0.00-0.03$ & - & - & 0.02 & - & - & 0.00 \\
\hline $\mathrm{B}_{2} \mathrm{O}_{3}$ & - & - & - & - & - & 3.00 & $2.78-3.28$ & - \\
\hline Total & 97.67 & & 96.58 & & 96.45 & 98.22 & & 85.35 \\
\hline
\end{tabular}

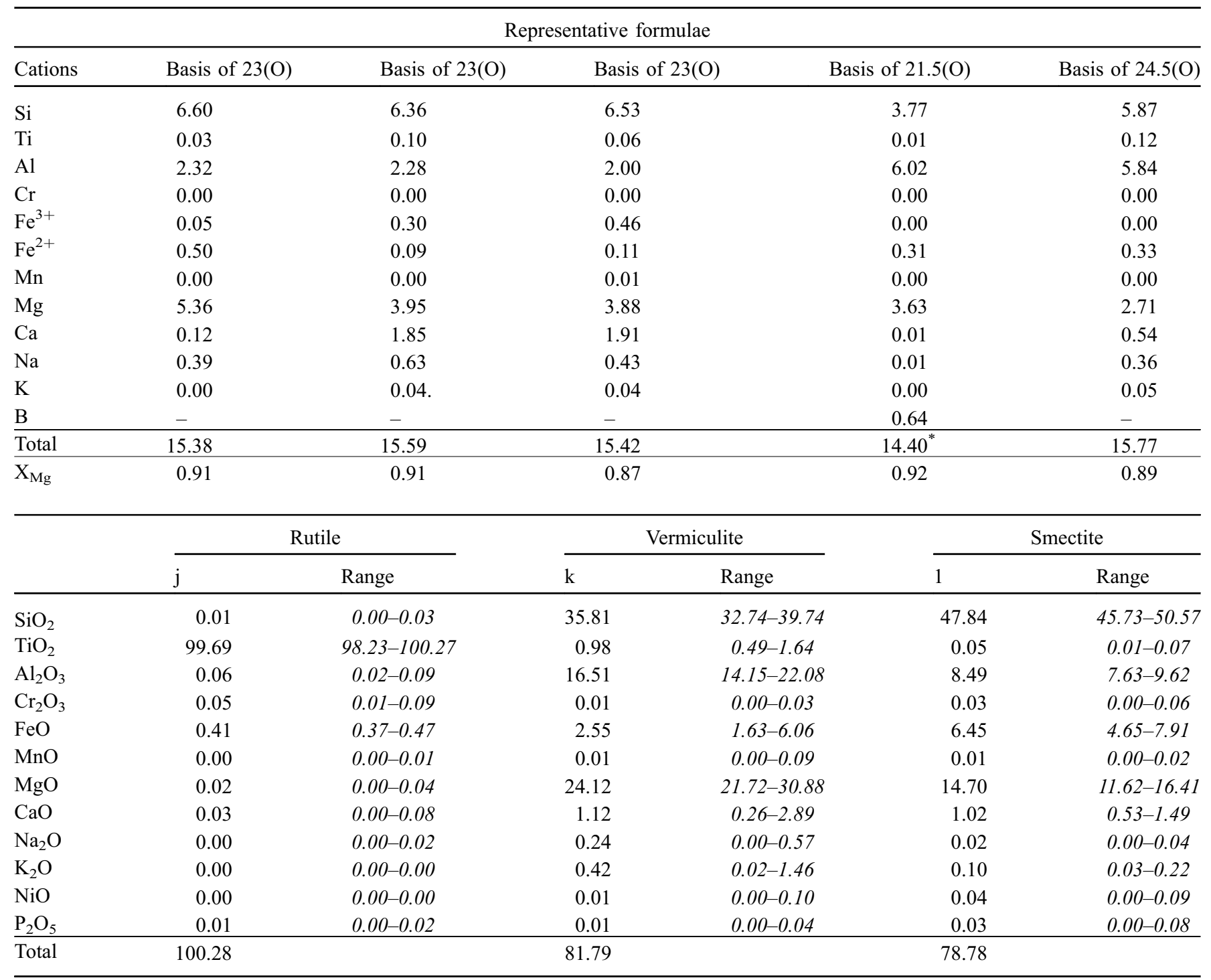

suggesting the involvement of evaporites or evaporitic brines have been observed so far in those assemblages;

- the assemblages commonly display coronitic textures, which are not recovered even as relics in the SBMS;

- they display different mineral assemblages, notably with mineral components (K-feldspar, quartz...) deriving from the surrounding crustal rocks.

Moreover, sapphirine is nearly devoid of $\mathrm{Cr}_{2} \mathrm{O}_{3}(<0.06 \mathrm{wt}$ $\%)$ and $\mathrm{NiO}(<0.02 \mathrm{wt} \%)$ in our sample collection, thus showing no direct evidence for mantle contribution. Therefore, none of the assemblages from the Castillon Massif and from the Caussou mantle body is a suitable candidate as source of the SBMS in the Lherz clastic deposits. Even a mix of several selected debris from these different sources will never reconstitute the SBMS. The lack of garnet in the Lherz SBMS is particularly significant in this respect, as well as the lack of quartz and feldspars debris that would have necessarily been a major contribution to our clastic association since, in the Castillon massif, the rare sapphirine-bearing rocks are hosted 

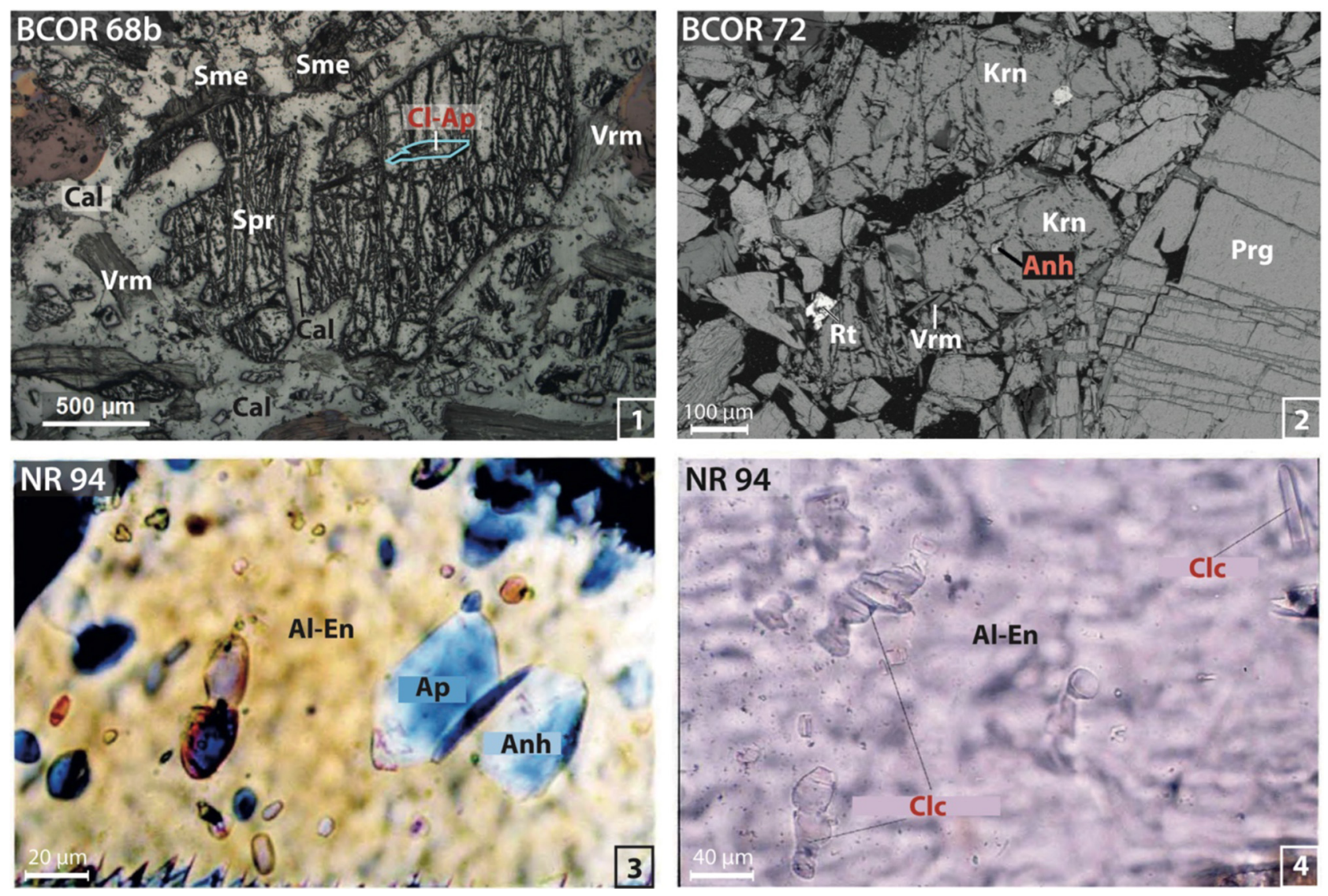

Fig. 10. Representative micrographs of the solid inclusions observed in minerals of the SBMS: (1) chlorapatite inclusion (outlined in blue) in a sapphirine crystal (reflected light; sample BCOR 68b); (2) anhydrite inclusion in a kornerupine crystal (back-scattered electron image; sample BCOR 72); (3) coalescent anhydrite and chlorapatite inclusions in an Al-bearing enstatite crystal (cross-polarized light; sample NR 94); (4) clinochlore inclusions in aluminous enstatite (plane-polarized light; sample NR 94, modified from F. Foucard, unpublished master thesis, Toulouse, 1997). Abbreviations from Whitney and Evans (2010).

by dominant kinzigites. In summary, up to the present day, a suitable protolith for the SBMS is unknown in the entire Pyrenees.

\subsubsection{Sapphirine-bearing rocks worldwide: the evaporitic signal}

Most sapphirine occurrences worldwide are linked to mafic and ultramafic rocks at granulite-facies conditions (e.g., Morishita et al., 2001; Jöns and Schenk, 2008; Chetouani et al., 2016). However, in several localities, a different type of sapphirine-bearing rocks is described and attributed to metamorphism of either evaporite deposits or of metasomatic assemblages implying fluids of meteoric, evaporitic or hydrothermal origin. An emblematic example is the pelitic whiteschists that occur as layers in talc-bearing series in Sar-e Sang (Afghanistan). There, sapphirine is found together with chlorite, cordierite, corundum, gedrite, kyanite, phlogopite, Na-plagioclase, minor pyrite, quartz, rutile, sillimanite, talc, tourmaline, and xenotime (Schreyer and Abraham, 1976), or with enstatite, forsterite, kornerupine, magnesite, phlogopite and spinel (Grew, 1988). In both cases, the authors interpret these rocks as highly metamorphosed pelitic sediments associated with evaporite deposits. In Ødegarden Verk (southern Norway), sapphirine is described in association with scapolite, Caamphibole, clinopyroxene, phlogopite, enstatite, rutile, chlorapatite and talc in scapolitized metagabbros in relation with metasomatism implying brine circulation (Engvik and Austrheim, 2010). In Vestfold Hills (East Antarctica), sapphirine associated with enstatite and spinel is reported in metasomatized, highly magnesian granulites hosted by paragneisses derived from evaporitic mudstones (Harley, 1993).

\subsubsection{Potential protolith(s) of the SBMS: cataclastic and metasomatized Keuper rocks?}

As demonstrated by the microprobe analyses of Table 3 , the protolith(s) of the SBMS must be extremely rich in $\mathrm{Al}_{2} \mathrm{O}_{3}$ and $\mathrm{MgO}$. This is consistent with former bulk-rock analyses by Monchoux (1972a, Tab. 6), even though the analysed rocks are not direct witnesses of their protolith(s) due to their tectonosedimentary nature. The presence of mineral species such as:

- boron-bearing kornerupine;

- F-, Cl- and Sr-rich apatite;

- anhydrite inclusions in several minerals;

points to the involvement of evaporites in producing the peculiar protolith of the Lherz SBMS. 
Table 4. Electron-microprobe analyses of solid inclusions of evaporitic affinity in enstatite crystals from sample NR 94. Average values of $n$ analyses, with $n=6$ for a), $n=3$ for b), $n=5$ for c).

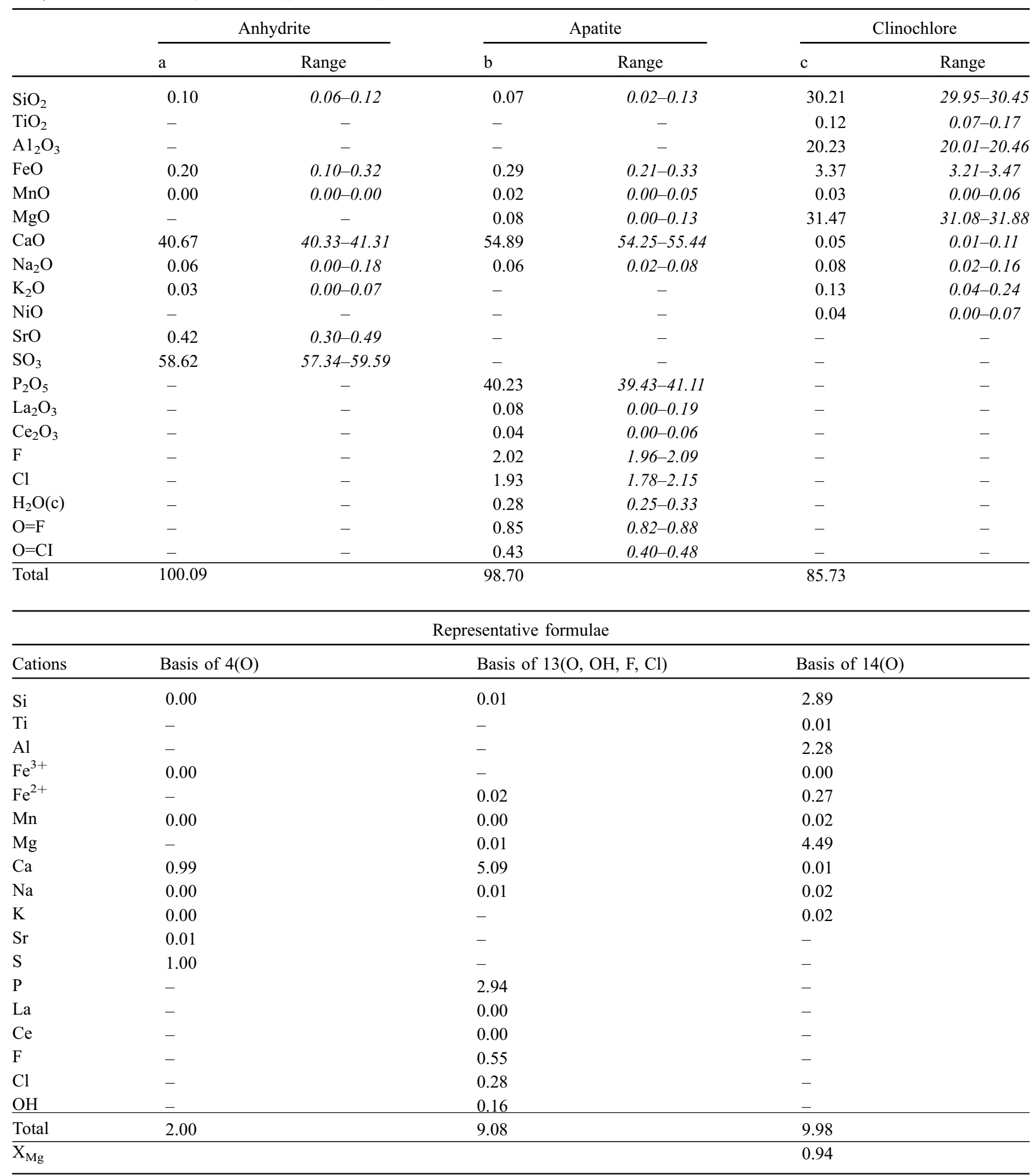


Table 5. LA-ICP-MS U-Pb isotope and age data for analyzed rutile grains in samples BCOR 72a-b. All errors are reported at $2 \sigma . f 206 \%=$ $\left(207 \mathrm{~Pb} / 206 \mathrm{Pbm}-207 \mathrm{~Pb} / 206 \mathrm{~Pb}^{*}\right) /\left(207 \mathrm{~Pb} / 206 \mathrm{Pbc}-207 \mathrm{~Pb} / 206 \mathrm{~Pb}^{*}\right) \times 100$ with $207 \mathrm{~Pb} / 206 \mathrm{~Pb}^{*}$ and $207 \mathrm{~Pb} / 206 \mathrm{Pbc}$ calculated at $100 \mathrm{Ma}$.

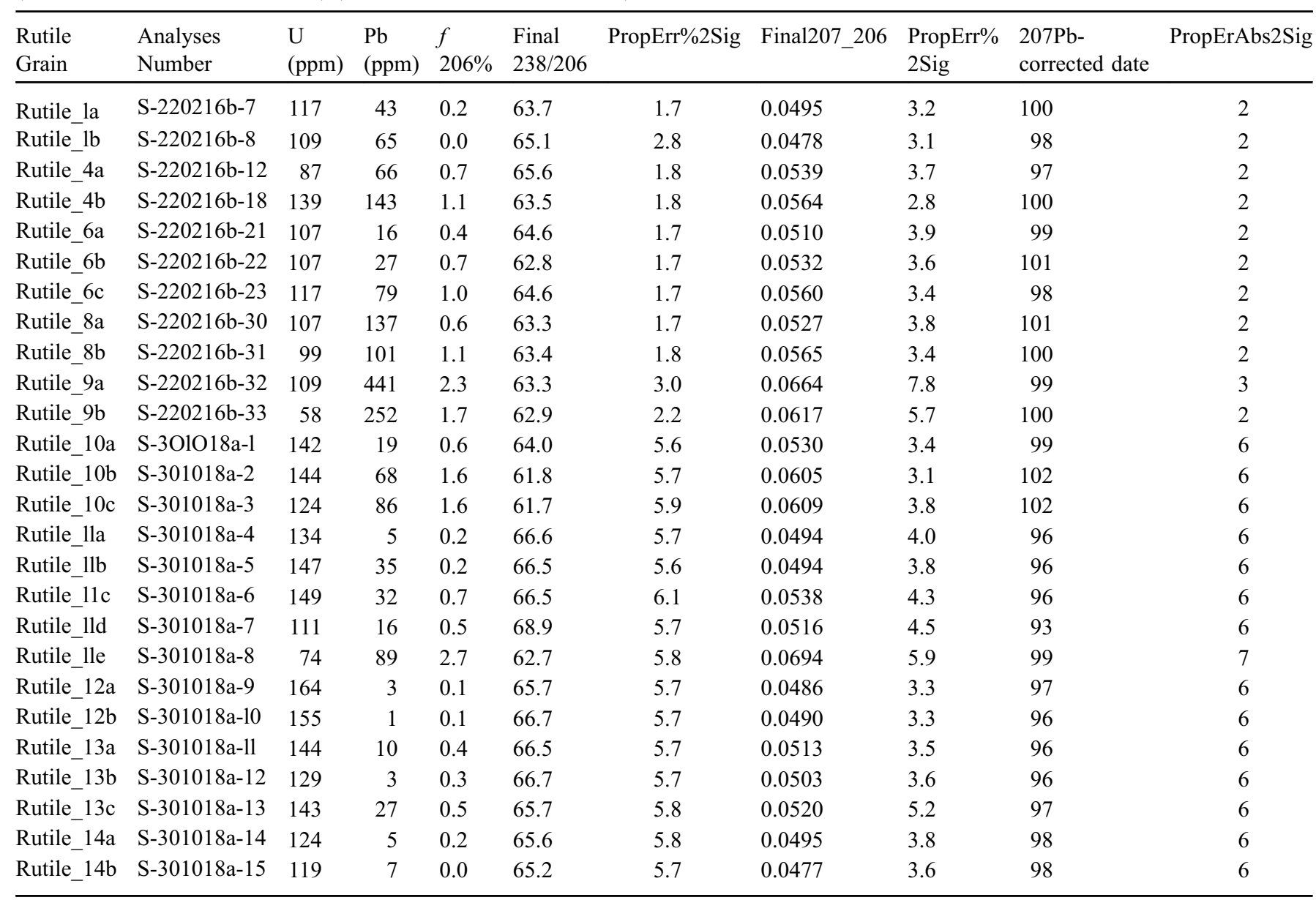

It is worth noting that Upper Triassic metasediments are present close to the southern border of the Lherz body, at Col d'Agnès (Ravier and Thiébaut, 1982; Ternet et al., 1997). These sediments underwent the HT-LP Cretaceous metamorphism and reached temperatures in the range of $550-600{ }^{\circ} \mathrm{C}$ coeval with mantle exhumation in the Aulus Basin (Clerc et al., 2015).

Cataclastic and metasomatized Keuper rocks are commonly found in shear zones related to the major tectonic discontinuities in the NPZ, notably the North Pyrenean Frontal Thrust (NPFT; e.g., Betchat and Bonrepaux, Central Pyrenees; Gleizes, 1971; Thiébaut et al., 1988, 1992) and the NPF (e.g., Larrau-Sainte-Engrâce; Thiébaut et al., 1992). At Betchat and Bonrepaux, a brecciated Late Triassic formation metamorphosed under lower epizonal conditions forms the sole of the NPFT (Gleizes, 1971; Thiébaut et al., 1988, 1992). It is made of gypsum lenses that host dominant magnesian (chlorite, dolomite, pargasite, phlogopite, talc) and aluminous (chlorite, scapolite, phlogopite) minerals, with minor celestite, ilmenite, quartz, sodic plagioclase, rutile and tourmaline (Gleizes, 1971; Thiébaut et al., 1992). This evaporitic material is found in a magnesian chlorite + illite rich matrix that hosts dolomite layers associated with talc and ophite stocks plurihectometric in size. In Arignac-Bedeilhac, north of the NPF, a similar situation is displayed by a Keuper epizonal brecciated formation that again contains (meta-) evaporites (anhydrite and gypsum) and several phases also found in the SBMS, notably: F- and Cl- rich apatite, chlorite, dolomite, magnesian hornblende, phlogopite, rutile, scapolite, talc and tourmaline (Bouscary, 1966; Thiébaut et al., 1988, 1992). The latter authors emphasized the high $\mathrm{Mg}, \mathrm{Al}, \mathrm{Na}, \mathrm{Cl}, \mathrm{F}$ and $\mathrm{B}$ contents of these rocks. In the western Pyrenees, Keuper epizonal cataclastic and metasomatized rocks are also described at the interface between exhumed mantle, felsic continental crustal units and syn-rift Mesozoic sediments in the Urdach and Saraillé massifs (Corre et al., 2018; Lagabrielle et al., 2019). They form a boudinaged layer consisting of a mixture of polymineralic clasts (dolomite, metasomatized felsic metamorphic rocks and micaschists, meta-ophites) embedded within a schistose matrix of talc and Mg-chlorite (Corre et al., 2018; Lagabrielle et al., 2019). A comparable epizonal Keuper formation is also known in the Basque-Cantabrian Basin (DeFelipe et al., 2017).

Whether metasomatic alteration was responsible at least for part of the Al-Mg richness in the SBMS prior to or during metamorphism is an open question. Indeed, the involvement of 


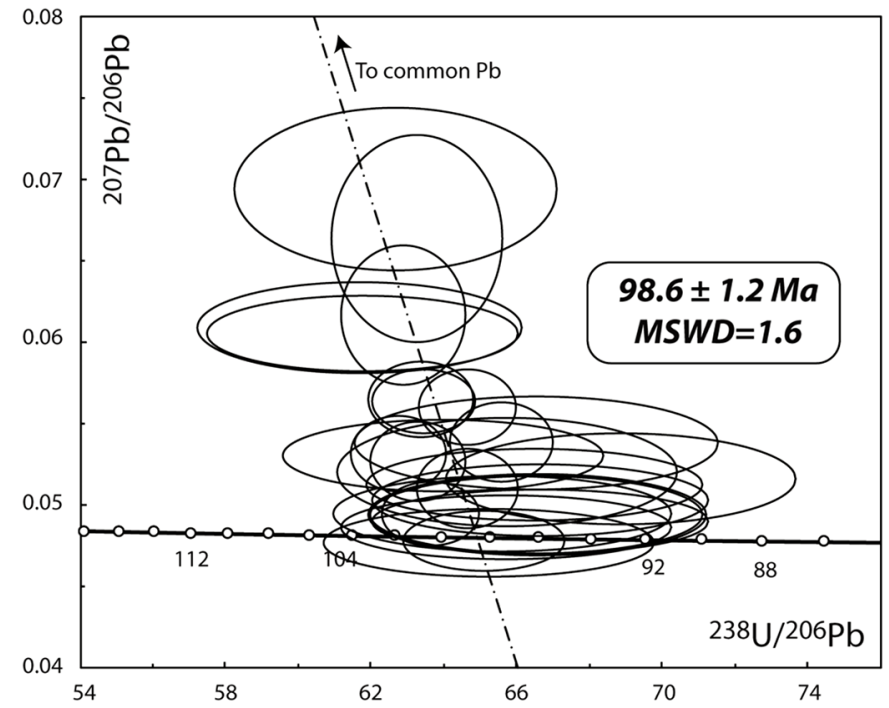

Fig. 11. Tera-Wasserburg concordia diagram for the U-Pb dating of rutile grains from samples BCOR68a-b. Error ellipses are plotted at $2 \sigma$. The lower intercept date of $98.6 \pm 1.2 \mathrm{Ma}$ is also reported with an error at $2 \sigma$.

Table 6. Bulk-rock analyses by Monchoux (1972a): 1, 2, 3: sapphirine-bearing rocks devoid of calcite, found at an increasing distance from the Lherz body; 4, 5: sapphirine-bearing rocks with calcite. Loi: loss on ignition.

\begin{tabular}{lcrrrr}
\hline & \multicolumn{1}{c}{2} & \multicolumn{1}{l}{3} & \multicolumn{1}{c}{4} \\
\hline $\mathrm{SiO}_{2}$ & 45.30 & 42.70 & 37.90 & 23.00 & 23.60 \\
$\mathrm{AI}_{2} \mathrm{O}_{3}$ & 15.30 & 16.30 & 19.10 & 9.40 & 11.10 \\
$\mathrm{Fe}_{2} \mathrm{O}_{3}$ & 5.90 & 6.00 & 7.90 & 3.50 & 6.80 \\
$\mathrm{MgO}$ & 22.30 & 24.60 & 17.20 & 14.60 & 13.00 \\
$\mathrm{CaO}$ & 1.40 & 3.20 & 10.70 & 23.90 & 20.80 \\
$\mathrm{Na}_{2} \mathrm{O}$ & 0.80 & 0.30 & 1.30 & 0.80 & 0.10 \\
$\mathrm{~K}_{2} \mathrm{O}$ & 0.08 & 0.10 & 0.80 & 0.04 & 0.00 \\
$\mathrm{CO}_{2}$ & - & - & - & 19.00 & 15.70 \\
Loi & 9.20 & 6.60 & 4.40 & 5.30 & 8.90 \\
\hline Total & 100.28 & 99.80 & 99.30 & 99.54 & 100.00 \\
\hline
\end{tabular}

metasomatic fluids is likely, considering reports from the western Pyrenees and the Basque-Cantabrian Basin (Corre et al., 2018; DeFelipe et al., 2017; Salardon et al., 2017; Lagabrielle et al., 2019). Derivation of $\mathrm{Mg}$ from the metasomatism of Mezosoic dolomitic sediments is unlikely. Indeed, although carbonate formations are frequently dolomitic in the area of HT-LP metamorphism of the NPZ (Fig. 1 (1)), this is considered to reflect metasomatic $\mathrm{Mg}$ addition which preceded talc formation. Such $\mathrm{Mg}$ addition was achieved through very high fluid-rock ratios, as exemplified by the huge Trimouns talc deposit (Boulvais et al., 2006; Boutin et al., 2016). Accordingly, the other possible source of $\mathrm{Mg}$ is the Keuper brines themselves.

All the geological markers around the Lherz sapphirine clastic deposits indicate that they reside at the location of a major detachment capping the exhumed mantle. Accordingly, we may assume that the original protolith(s) of the Lherz SBMS evolved in a detachment fault, assisted by variable amount of fluids containing elements including $\mathrm{Si}, \mathrm{Mg}, \mathrm{Fe}, \mathrm{Ca}, \mathrm{Cl}, \mathrm{B}, \mathrm{Sr}, \mathrm{F}$. Transformation of Triassic material along major detachment faults has already been emphasized by Corre et al. (2018). The latter authors describe tectonic contacts between mantle rocks and Mesozoic sediments characterized by the occurrence of Triassic cataclastic material affected by intense syn-kinematic hydrothermal circulations. These contacts represent the detachment faults along which subcontinental mantle was exhumed toward upper crustal levels during the opening of the AlbianCenomanian rift at the locus of the future NPZ.

\subsubsection{P-T formation conditions of the Lherz SBMS protolith(s)}

Calculating $\mathrm{P}$ and $\mathrm{T}$ formation conditions from the SBMS is problematic since:

- the SBMS, owing to its tectono-sedimentary nature, might derive either from a single protolith or from a mixture of several protoliths;

- even in the case of a single protolith, the sapphirine-bearing clasts are too small to identify the entire primary paragenesis and the whole-rock chemistry that are needed for multi-equilibrium thermobarometry;

- thermodynamic data for sapphirine remain highly uncertain (Podlesskii et al., 2008; Wheller and Powell, 2014);

- a contribution of evaporite-derived fluids is likely thus making the P-T calculation highly dependent on reduced $\mathrm{H}_{2} \mathrm{O}$ activity (Nijland et al., 1998; Engvik and Austrheim, 2010).

Consequently, we will only attempt to fix bounds to the P-T estimates.

In the absence of corundum (or pyrope), a lower $\mathrm{T}$ limit is given by the extent of Tschermak substitution in orthopyroxene, through the fluid-independent reaction enstatite + corundum $=\mathrm{MgAl}_{2} \mathrm{SiO}_{6}$ ('Mg-Tschermak'). The 5-6 mol\% MgTschermak measured in aluminous enstatite indicate a minimum $\mathrm{T}$ of about $550{ }^{\circ} \mathrm{C}$ at low pressures and of $\sim 600^{\circ} \mathrm{C}$ at $1.5 \mathrm{GPa}$ (e.g., Gasparik, 1994), regardless of fluid presence or composition.

Another fluid-independent indication is given by the stability of anthophyllite ( $v s$. talc + enstatite in the $\mathrm{MgO}-\mathrm{SiO}_{2}-$ $\mathrm{H}_{2} \mathrm{O}$ system), which implies a minimum $\mathrm{T}$ varying from $\sim 550^{\circ} \mathrm{C}$ at very low pressure to $\sim 750^{\circ} \mathrm{C}$ at $1 \mathrm{GPa}$ (Berman et al., 1986).

According to the inclusion and intergrowth relationships observed in the clasts, the pairs enstatite-chlorite, sapphirineanthophyllite and sapphirine-spinel were stable in the source rock of the SBMS (Tab. 2, Fig. 5(1), (5), (6), Fig. 6(1) and Fig. 10(4)). In the magnesian system, the stability of sapphirine $\left(+\mathrm{H}_{2} \mathrm{O}\right)$ combined with those of chlorite + enstatite and of anthophyllite define a relatively narrow crescent in the P-T field, about $50^{\circ} \mathrm{C}$ wide in its broadest part, concave toward the $\mathrm{P}$-axis and extending from about $600^{\circ} \mathrm{C}$ at very low $\mathrm{P}$ to about $800^{\circ} \mathrm{C}$ near $1 \mathrm{GPa} \mathrm{P}_{\mathrm{H} 2 \mathrm{O}}$ (Seifert, 1974; Berman et al., 1986). However, all the reactions involved are dehydration reactions and so the whole crescent may shift to lower temperatures with decreasing $\mathrm{H}_{2} \mathrm{O}$ activity. 
Leaving aside the ultrahigh-temperature assemblages like sapphirine-quartz or spinel-quartz (e.g., Wheller and Powell, 2014), crystallization of sapphirine-bearing assemblages in silica-poor systems most commonly indicates facies conditions of amphibolite-granulite boundary to granulitic, with temperatures ranging from $700^{\circ}$ to $900^{\circ} \mathrm{C}$ and pressures from 0.3 to 1.1 GPa (e.g., Ackermand et al., 1982; Windley et al., 1984; Christy, 1989; Vry and Cartwright, 1994). For the closest natural assemblages to the SBMS found in the literature, the P-T estimates are around $700-800^{\circ} \mathrm{C}$ and $0.35-1.0 \mathrm{GPa}$ (Ackermand et al., 1982; Vry and Cartwright, 1994). One should however bear in mind that:

- in the magnesian system, from about 0.03 to at least $0.7 \mathrm{GPa} \mathrm{P}_{\mathrm{H} 2 \mathrm{O}}$, sapphirine $\left(+\mathrm{H}_{2} \mathrm{O}\right)$ may form from chlorite + spinel + corundum at temperatures between $600^{\circ}$ and $750{ }^{\circ} \mathrm{C}$, depending on pressure (Seifert, 1974);

- at any given pressure, chlorite dehydrates at a less than $50{ }^{\circ} \mathrm{C}$ higher $\mathrm{T}$ than sapphirine formation (Seifert, 1974); - in the presence of brines and/or lowered $\mathrm{H}_{2} \mathrm{O}$ activity, dehydration reactions (the sapphirine-forming ones in particular) occur at lower temperatures, by as much as $120^{\circ} \mathrm{C}$ lower for $\mathrm{H}_{2} \mathrm{O}$ activity reduced to 0.4 (e.g., Simon and Chopin, 2001).

Accordingly, and given the abundance of vermiculites which likely derive from phlogopite or aspidolite, the best $\mathrm{T}$ estimate range for the development of the SBMS is 550$700{ }^{\circ} \mathrm{C}$, for a maximum $\mathrm{P}$ of $1 \mathrm{GPa}$. If one then assumes that the enstatite-sapphirine pair was stable in the source rock, the low Al-content of enstatite points to temperatures around 600$650{ }^{\circ} \mathrm{C}$ and pressures of a few kilobars (Fig. 4 in Gasparik, 1994). Furthermore, the instability of the alternative assemblage cordierite-spinel implies a minimum $\mathrm{P}$, decreasing at such temperatures from $\sim 0.3 \mathrm{GPa}$ to $\sim 0.1 \mathrm{GPa}$ with decreasing $\mathrm{H}_{2} \mathrm{O}$ activity (Podlesskii et al., 2008, his Fig. 7), which is definitely the case in the presence of metamorphic brines (e.g., Aranovich and Newton, 1997).

The Lherz area is, together with the Boucheville basin, the place where the North Pyrenean HT-LP Cretaceous metamorphism reached the highest temperatures (Golberg and Leyreloup, 1990; Clerc et al., 2015; Chelalou et al., 2016). In the Aulus Basin, the highest peak temperature has been so far estimated to a maximum of $625^{\circ} \mathrm{C}$ by RSCM in Liassic rocks located $1.5 \mathrm{~km}$ to the south of the Lherz body, whereas peak temperatures around $550{ }^{\circ} \mathrm{C}$ are commonly obtained in Triassic ( $1 \mathrm{~km}$ to the south of the Lherz body) and Jurassic ( $300 \mathrm{~m}$ to $4.4 \mathrm{~km}$ from the Lherz body edges) metasediments (Clerc et al., 2015). Hence, the SBMS records metamorphic $\mathrm{T}$ conditions that equal or slightly exceed the highest values in the area.

In the context of extreme crustal thinning during the formation of the Aulus Basin (Lagabrielle et al., 2016), the maximum $\mathrm{P}$ conditions for the formation of the SBMS are directly linked to the initial thickness of the pre-rift (Triassic to Aptian) + syn-rift (Albian to Turonian) sedimentary pile above the exhumed mantle. Compilation of existing stratigraphic data at the scale of the entire NPZ suggests a maximum thickness around $6-8 \mathrm{~km}$ for that sedimentary pile (Debroas, 1978; Canérot and Delavaux, 1986; Canérot, 1991). Therefore, the combined experimental and thermodynamic data allowing for sapphirine formation in the $0.1-0.2 \mathrm{GPa}$ range, especially at relatively 'low' $\mathrm{T}$ near $600-650{ }^{\circ} \mathrm{C}$ and under reduced $\mathrm{H}_{2} \mathrm{O}$ activity (Podlesskii et al., 2008), are consistent with the geological constraints.

\subsection{Timing of the events experienced by the SBMS}

The U-Pb dating of rutile, which provide an apparent Cenomanian age (section 4.4), must be confronted with mineralogical and textural features before being ascribed to the formation of the SBMS. Three a priori scenarii may be envisioned:

1) the dated rutile grains originate from a Variscan protolith which was brecciated and sedimented before the Cenomanian. This sediment was re-heated during the Cretaceous HT-LP metamorphic episode;

2) the protolith of samples BCOR 68a-b experienced a unique metamorphic episode that occurred during the Cretaceous and it was subsequently brecciated and sedimented at a shallow depth during the Upper Cretaceous;

3) same history as (2) but brecciation and sedimentation occurred later, most likely during the Paleogene Pyrenean shortening and even more recently regarding sedimentation.

We discard hypothesis (1) on the basis of three arguments. As mentioned previously, Variscan rocks with such mineralogy and compositions are unknown in the regional basement. Moreover, even though such rocks would be a very discrete component of that basement, it is quite impossible to imagine that the sediments contain only clasts issued from that component whilst common major minerals from the Variscan crust, namely quartz and feldspars issued from granitoids and felsic metamorphic rocks, are lacking (Tab. 2). Finally, hypothesis (1) is not consistent with the rock textures. Closure temperature of the $\mathrm{U}-\mathrm{Pb}$ system in rutile is strongly controlled by the grain size and considered to be around $600{ }^{\circ} \mathrm{C}$ for crystals with sizes ranging from 100 to $200 \mu \mathrm{m}$, although it can be as low as $c a .400^{\circ} \mathrm{C}$ (Cherniak, 2000; Mezger et al., 1989; Meinhold, 2010; Blackburn et al., 2011). Such a temperature range is however compatible with the Cretaceous metamorphic peak temperatures known in the Lherz area (Clerc et al., 2015), i.e. with amphibolite facies. In such conditions, recrystallization of a sediment associating clasts of very different size and compositions would induce characteristic textural features such as growth of large clasts at the expense of minor similar ones at their contact, which is never observed. Rather, all the observed textures argue for fracturing, disaggregation and dispersion of the largest crystals (see section 5.1). Accordingly, we consider that the $c a$. $100 \mathrm{Ma}$ date does not correspond to a resetting event. Hypothesis (3) is also difficult to reconcile with the fact that none of the samples forming the SBMS display clasts deriving from the surrounding Jurassic to Cretaceous formations of the Aulus Basin which fed, however, the volumetrically very dominant Lherz breccias. On the opposite, hypothesis (2) fits U-Pb geochronological data and the prevalence of ultramafic and Triassic clasts in the sapphirine-bearing breccias and their systematic location in contact with ultramafic bodies. Accordingly, we conclude that metamorphism and brecciation occurred during the Cretaceous rifting event. The timing of sedimentation is however poorly constrained. 


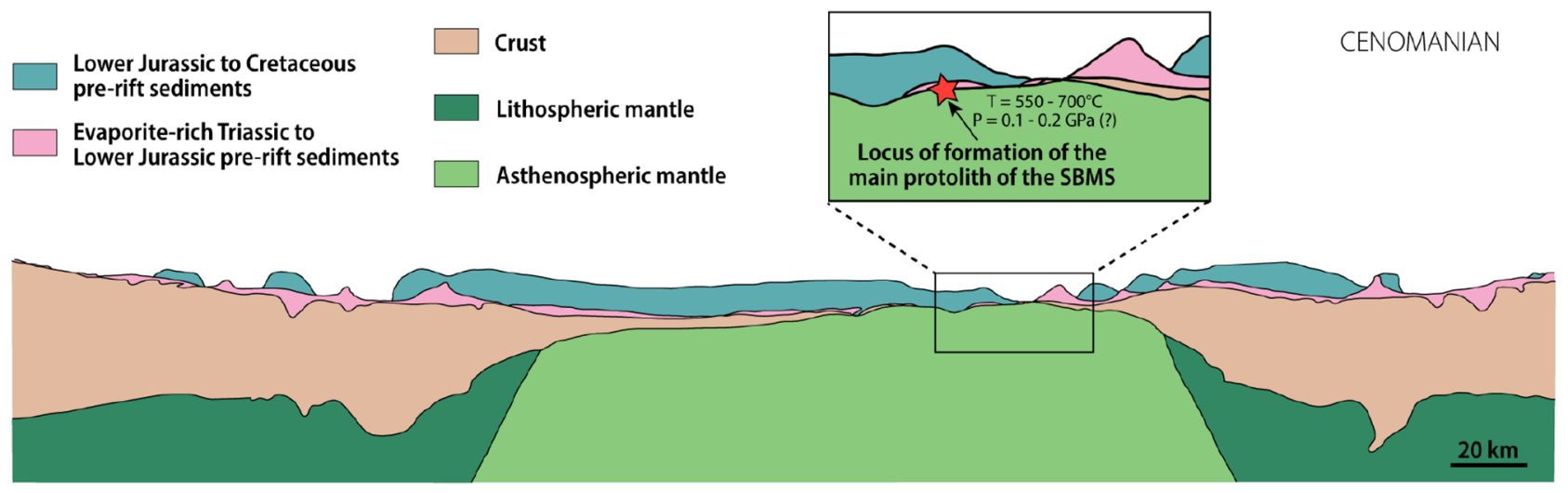

Fig. 12. Position of the main protolith of the SBMS suggested from this study in the Pyrenean rift (red star). The geometry of the rift is redrawn after Duretz et al. (2019). The P-T conditions of metamorphism of the Upper Triassic to Lower Jurassic protolith on contact with the asthenospheric mantle deduced from this study are given with their uncertainties in the inset.

\subsection{A possible model of emplacement of the sapphirine-bearing rocks}

The sapphirine-bearing rocks are found only in a contact zone at the border of the Lherz body and constitute the lowermost unit of the Lherz breccias. Therefore, according to recent models of subcontinental mantle exhumation in the NPZ (e.g., Jammes et al., 2009; Lagabrielle et al., 2016), they are good candidates to represent the basal portion of the metamorphic sedimentary pile that came in tectonic contact with the exhumed peridotites during the Cretaceous extensional event. The $\mathrm{T}$ estimates for the crystallization of the SBMS material $\left(550-700^{\circ} \mathrm{C}\right.$, and more probably $\left.600-650^{\circ} \mathrm{C}\right)$ as well as the $\mathrm{U}-\mathrm{Pb}$ geochronological data are consistent with a formation contemporaneous with the Pyrenean high $\mathrm{T}$ metamorphic event, i.e. during the activity of the detachment fault which accommodated the uplift of the peridotites beneath the opening Aulus Basin (Fig. 12).

In this study, we have reported numerous evidence for a dominant Keuper origin of the material reworked in the sapphirine-bearing rocks. We also argued that the SBMS protolith(s) derive from the metasomatic transformation of tectonized Keuper evaporitic sediments under the influence of fluid circulations. Thus, we may speculate that the SBMS protolith(s) originated along a major detachment fault at the final stages of the extreme crustal thinning when the mantle rocks reached the base of the Mesozoic sedimentary pile, under severe temperature conditions.

Our understanding of the Cretaceous mantle exhumation processes in the Pyrenees lacks geological constraints and still remains incomplete. In this topic, our study provides the following results:

- the brecciated texture and the presence of unequivocal sedimentary features in the sapphirine-bearing rocks show that the metasomatized Keuper material first crossed the ductile-brittle transition and was then mechanically disaggregated before experiencing some kind of winnowing in underwater conditions;

- we infer that these rocks underwent minor spatial remobilization since their surface exposure, which is consistent with the poor mixing observed between the different sources.
Accordingly, the most plausible scenario for the origin of the sapphirine-bearing rocks that integrates all our observations is as follows:

(i) the progressive exhumation of the extensional detachment and its footwall toward shallow levels induced the transition from ductile to brittle deformation responsible for the initial fracturing of the rocks and crystals;

(ii) uplift was accompanied by progressive unroofing of deep levels of the detachment fault on the floor of the basin;

(iii) exposure of the fault rocks allowed the reworking and primary sorting of the cataclastic material by gravitydriven processes.

Determining whether these latter reworking processes occurred entirely during the exhumation event or somewhat later is beyond the scope of the present paper and needs a discussion on the whole system of the Lherz breccias, including the overwhelming carbonate-types.

In the proposed scenario, the status of the sparitic calcite which forms the cement between the fragments and fills cracks within monomineralic clasts in Type II samples is equivocal. It might be a primary component (ophicalcitic cement, as exemplified by Denny et al. (2016), or dolomitic component of Keuper sediments themselves), metamorphosed and subsequently redistributed, or it might have been introduced only during the brecciation stage like the calcitic cement of the Lherz breccias. Deciphering between these two hypotheses requires further investigation (e.g., RSCM, stable isotopes geochemistry).

\section{Conclusion}

This detailed petrographic study of sapphirine-bearing rocks exposed in a contact zone between the Lherz mantle peridotites and the Lherz breccias reveals that some samples are composed of polymineralic clasts and isolated minerals that derive from well-recognized protoliths, mostly ultramafic rocks and Triassic meta-ophites and "micaceous hornfels". However, a large portion of the sapphirine-bearing clastic suite is composed of mono- and polymineralic debris that derive from unknown protolith(s). We thus defined a "sapphirine- 
bearing mineral suite" (SBMS) composed of monomineralic debris including: sapphirine + enstatite + aluminous spinel + Mg-amphiboles + Ca-amphiboles + kornerupine + accessory minerals (tourmaline, rutile, vermiculite and smectite).

The mineralogical study of the SBMS points to a peculiar $\mathrm{Al}-\mathrm{Mg}$-rich chemistry and reveals the presence of F-, Cl-, Srrich evaporitic inclusions in minerals of the Al-Mg-rich suite. This is consistent with a derivation of the SBMS from the metamorphic transformation of Keuper evaporitic sediments under high $\mathrm{T}$ and low $\mathrm{P}$ conditions, typical of the Cretaceous Pyrenean metamorphism. This contradicts the former interpretation of the Lherz sapphirine-bearing suite as crustal basement felsic rocks modified at depth along the contact with the ultramafic rocks of the Lherz body during their ascent towards shallower depths. Our hypothesis is also supported by the location of the sapphirine-bearing rocks at the precise contact zone between the exhumed Lherz body and the Lherz breccias.

According to recent models of subcontinental mantle exhumation in the NPZ (Lagabrielle and Bodinier, 2008; Clerc et al., 2015; Lagabrielle et al., 2016), we propose that the sapphirine-bearing rocks represent the first formation deposited over the peridotites exposed on the floor of the Aulus Basin due to the activity of a detachment fault. The T estimates for the crystallization of the SBMS material $\left(550-700^{\circ} \mathrm{C}\right.$, and more probably $600-650^{\circ} \mathrm{C}$ ) and $\mathrm{U}-\mathrm{Pb}$ ages of $\mathrm{ca}$. $100 \mathrm{Ma}$ obtained on rutile are consistent with a formation contemporaneous with the Pyrenean HT metamorphic event, which is during the activity of the fault that accommodated the uplift of the peridotites beneath the opening Aulus Basin.

Field and microscopic observations imply that the sapphirine-bearing sandstones and breccias formed in a context of active tectonics allowing for the brecciation of a variety of lithological assemblages and their mechanical and sedimentary mixing. A scenario that integrates all our observations is as follows:

(i) initial fracturing of the rocks and crystals due to progressive uplift of the extensional detachment toward shallow levels crossing the transition from ductile to brittle deformation;

(ii) progressive unroofing of deep levels of the detachment fault on the floor of the basin;

(iii) exposure of the fault rocks followed by reworking and primary sorting of the cataclastic material by gravitydriven processes.

\section{Declaration of interest}

The authors declare that they have no conflicts of interest in relation to this article

\section{Supplementary Material}

Supplementary Material 1. Operating conditions for the LA-ICP-MS equipment.

Supplementary Material 2. Thin section descriptions.

Supplementary Material 3. BSE images of some rutile grains used for $\mathrm{U}-\mathrm{Pb}$ dating.

The Supplementary Material is available at https://www.bsgfjournal.org/10.1051/bsgf/2019015/olm.
Acknowledgements. This work was supported by the UMR 6118 - Géosciences Rennes and by the RGF-Pyrénées project of the "Bureau de Recherches Géologiques et Minières" (BRGM, T. Baudin, manager). We warmly thank B. Azambre for his help on petrographic analysis and for fruitful discussions at Géosciences Rennes. We also thank M. Ducoux and an anonymous reviewer for their insightful comments which helped to improve the clarity of the manuscript.

\section{References}

Abraham K, Monchoux P, Roux L, Seifert F. 1977. Observations sur les exsolutions dans les orthoamphiboles des roches à sapphirine des Pyrénées. Bulletin de la Société française de Minéralogie et Cristallographie 100: 329-333.

Ackermand D, Herd RK, Windley BF. 1982. Chemographic relationships in sapphirine-bearing rocks of the Limpopo belt, Southern Africa. Revista Brasileira de Geociencias 12(1-3): 292-300.

Albarède F, Michard-Vitrac A. 1978. Age and significance of the north-pyrenean metamorphism. Earth and Planetary Science Letters 40: 327-332.

Avé Lallemant HG. 1968. Structural and petrofabric analysis of an "alpine-type" peridotite: the lherzolite of the French Pyrénées. Leidse Geologische Mededelingen 42: 1-57.

Aranovich LY, Newton RC. 1997. $\mathrm{H}_{2} \mathrm{O}$ activity in concentrated $\mathrm{KCl}$ and $\mathrm{KCl}-\mathrm{NaCl}$ solutions at high temperatures and pressures measured by the brucite-periclase equilibrium. Contributions to Mineralogy and Petrology 127(3): 261-271.

Arima M, Barnett RL. 1984. Sapphirine bearing granulites from the Sipiwesk Lake area of the late Archaean Pikwitonei granulite terrain, Manitoba, Canada. Contributions to Mineralogy and Petrology 88: 102-112.

Asti R, Lagabrielle Y, Fourcade S, Corre B, Monié P. 2019. How do continents deform during mantle exhumation? Insights from the northern Iberia inverted paleo-passive margin, western Pyrenees (France). Tectonics. DOI: 10.1029/2018TC005428.

Azambre B, Rossy M, Lago M. 1987. Caractéristiques pétrologiques des dolérites tholéiitiques d'âge triasique (ophites) du domaine pyrénéen. Bulletin de Minéralogie 110: 379-396.

Berman RG, Engi M, Greenwood HJ, Brown TH. 1986. Derivation of internally-consistent thermodynamic data by the technique of mathematical programming: a review with application the system MgO-SiO2-H2O. Journal of Petrology 27(6): 1331-1364.

Bixel F, Lucas C. 1987. Approche géodynamique du Permien et du Trias des Pyrénées dans le cadre du Sud-Ouest Européen. Cuadernos de Geología Ibérica = Journal of Iberian Geology: an international publication of earth sciences 11: 57-82.

Blackburn T, Bowring SA, Schoene B, Mahan K, Dudas F. 2011. U$\mathrm{Pb}$ thermochronology: creating a temporal record of lithosphere thermal evolution. Contributions to Mineralogy and Petrology 162 (3): 479-500.

Bodinier JL, Guiraud M, Fabriès J, Dostal J, Dupuy C. 1987. Petrogenesis of layered pyroxenites from the Lherz, Freychinede and Prades ultramafic bodies (Ariege, French Pyrenees). Geochimica et Cosmochimica Acta 51(2): 279-290.

Boillot G, Grimaud S, Mauffret A, et al. 1980. Ocean-continent boundary off the Iberian margin: a serpentinite diapir west of the Galicia Bank. Earth and Planetary Science Letters 48(1): 23-34.

Boulvais P, De Parseval P, D'Hulst A, Paris P. 2006. Carbonate alteration associated with talc-chlorite mineralization in the eastern Pyrenees, with emphasis on the St. Barthelemy Massif. Mineralogy and Petrology 88(3-4): 499-526. 
Boulvais P, Ruffet G, Cornichet J, Mermet M. 2007. Cretaceous albitization and dequartzification of Hercynian peraluminous granite in the Salvezines Massif (French Pyrenees). Lithos 93: 89-106.

Boutin A, de Saint Blanquat M, Poujol M, et al. 2016. Succession of Permian and Mesozoic metasomatic events in the eastern Pyrenees with emphasis on the Trimouns talc-chlorite deposit. International Journal of Earth Sciences 105: 747-770.

Bouscary C. 1966. Les minéraux de métamorphisme du Trias de Bédeilhac (Ariège). Bulletin de la Société d'Histoire Naturelle de Toulouse 102(5): 286-291.

Briqueu L, Innocent C. 1993. Datation U/Pb sur zircon et géochimie isotopique $\mathrm{Sr}$ et $\mathrm{Nd}$ du volcanisme permien des Pyrénées occidentales (Ossau et Anayet). Comptes rendus de l'Académie des sciences. Série 2, Mécanique, Physique, Chimie, Sciences de l'univers, Sciences de la Terre 316(5): 623-628.

Canérot J. 1991. Comparative study of the eastern Iberides (Spain) and the western Pyrenees (France) Mesozoic basins. Palaeogeography, palaeoclimatology, palaeoecology 87(51-4): 1-28.

Canérot J, Delavaux F. 1986. Tectonique et sédimentation sur la marge nord-ibérique des chaînons béarnais (Pyrénées-béarnaises). Remise en question de la signification des lherzolites du sommet de Saraillé. Comptes rendus de l'Académie des sciences. Série 2, Mécanique, Physique, Chimie, Sciences de l'univers, Sciences de la Terre 302(15): 951-956.

Chelalou R, Nalpas T, Bousquet R, et al. 2016. New sedimentological, structural and paleo-thermicity data in the Boucheville Basin (eastern North Pyrenean Zone, France). Comptes Rendus de Géoscience 348(3-4): 312-321.

Cherniak D. 2000. Pb diffusion in rutile. Contributions et Mineralogy and Petrology 139: 198-207.

Chetouani K, Bodinier JL, Garrido CJ, Marchesi C, Amri I, Targuisti K. 2016. Spatial variability of pyroxenite layers in the Beni Bousera orogenic peridotite (Morocco) and implications for their origin. Comptes Rendus de Géoscience 348(8): 619-629.

Choukroune P. 1970. Contribution à l'étude structurale de la zone métamorphique nord-pyrénéenne ; tectonique et métamorphisme des formations secondaires de la forêt de Boucheville (Pyrénées orientales). Bulletin du Bureau des Recherches Géologiques et Minières 4: 46-63.

Choukroune P. 1973. La brèche de Lherz dite « d'explosion liée à la mise en place des lherzolites » est une brèche sédimentaire d'âge Cénozoïque (Pyrénées ariégeoises). Comptes Rendus de l'Académie des Sciences, Série D 277: 2621-2624.

Choukroune P. 1976. Structure et évolution tectonique de la Zone Nord-Pyrénéenne: analyse de la déformation dans une portion de chaîne à schistosité subverticale. Mémoires de la Société géologique de France 127.

Christy AG. 1989. The stability of sapphirine + clinopyroxene: implications for phase relations in the $\mathrm{CaO}-\mathrm{MgO}-\mathrm{Al}_{2} \mathrm{O}_{3}-\mathrm{SiO}_{2}$ system under deep-crustal and upper mantle conditions. Contributions to Mineralogy and Petrology 102: 422-428.

Clerc C, Lagabrielle Y, Neumaier M, Reynaud JY, de Saint Blanquat M. 2012. Exhumation of subcontinental mantle rocks: evidence from ultramafic-bearing clastic deposits nearby the Lherz peridotite body, French Pyrenees. Bulletin de la Société Géologique de France 183(5): 443-459.

Clerc C, Boulvais P, Lagabrielle Y, de Saint Blanquat M. 2014. Ophicalcites from the northern Pyrenean belt: a field, petrographic and stable isotope study. International Journal of Earth Sciences 1-23.

Clerc C, Lagabrielle Y. 2014. Thermal control on the modes of crustal thinning leading to mantle exhumation: insights from the Cretaceous Pyrenean hot paleomargins. Tectonics 33: 1340-1359.
Clerc C, Lahfid A, Monié P, et al. 2015. High-temperature metamorphism during extreme thinning of the continental crust: a reappraisal of the north Pyrenean paleo-passive margin. Solid Earth Discussions 6: 1-61.

Clerc C, Lagabrielle Y, Labaume P, et al. 2016. Basement-Cover decoupling and progressive exhumation of metamorphic sediments at hot rifted margin. Insights from the Northeastern Pyrenean analog. Tectonophysics 686: 82-97.

Conquéré F. 1978. Pétrologie des complexes ultramafiques de l'Ariège, Doctoral Dissertation, Université Pierre et Marie Curie, 333 p.

Corre B, Lagabrielle Y, Labaume P, Fourcade S, Clerc C, Ballèvre M. 2016. Deformation associated with mantle exhumation in a distal, hot passive margin environment: new constraints from the Saraillé Massif (Chaînons Béarnais, North-Pyrenean Zone). Comptes Rendus de Géoscience 348(3-4): 279-289.

Corre B, Boulvais P, Boiron MC, Lagabrielle Y, Marasi L, Clerc C. 2018. Fluid circulations in response to mantle exhumation at the passive margin setting in the North Pyrenean Zone, France. Mineralogy and Petrology 112(5): 647-670.

Costa S, Maluski H. 1988. Use of the ${ }^{40} \mathrm{Ar}-{ }^{39} \mathrm{Ar}$ stepwise heating method for dating mylonite zones: an example from the St. Barthélémy massif (Northern Pyrenees, France). Chemical Geology: Isotope Geoscience section 72(2): 127-144.

Dauteuil O, Ricou LE. 1989. Une circulation de fluides de hautetempérature à l'origine du métamorphisme crétacé nord-pyrénéen. Geodinamica Acta 3(3): 237-249.

Debroas EJ. 1978. Évolution de la fosse du flysch ardoisier de l'Albien supérieur au Sénonien inferieur (zone interne métamorphique des Pyrénées navarro-languedociennes). Bulletin de la Société géologique de France 7(5): 639-648.

Debroas EJ, Bilotte M, Canérot J, Astruc G. 2010. Réinterprétation des brèches de la Faille nord-pyrénéenne ariégeoise (France). Bulletin de la Société d'Histoire Naturelle de Toulouse 146: 77-88.

DeFelipe I, Pedreira D, Pulgar JA, Iriarte E, Mendia M. 2017. Mantle exhumation and metamorphism in the Basque-Cantabrian Basin (N Spain): stable and clumped isotope analysis in carbonates and comparison with ophicalcites in the North-Pyrenean Zone (Urdach and Lherz). Geochemistry, Geophysics, Geosystems 18 (2): 631-652.

Denèle Y, Paquette JL, Olivier P, Barbey P. 2012. Permian granites in the Pyrenees: the Aya pluton (Basque Country). Terra Nova 24(2): 105-113.

Denèle Y, Laumonier B, Paquette JL, Olivier P, Gleizes G, Barbey P. 2014. Timing of granite emplacement, crustal flow and gneiss dome formation in the Variscan segment of the Pyrenees. Geological Society, London, Special Publications 405(1): 265-287.

Denny AR, Kelley DS, Früh-Green GL. 2016. Geologic evolution of the Lost City hydrothermal field. Geochemistry, Geophysics, Geosystems 17(2): 375-394.

de Saint Blanquat M., Bajolet F, Grand'Homme A, et al. 2016. Cretaceous mantle exhumation in the central Pyrenees: new constraints from the peridotites in eastern Ariège (North Pyrenean zone, France). Comptes Rendus de Géoscience 348(3-4): 268-278.

Ducoux M. 2017. Structure, thermicité et évolution géodynamique de la Zone Interne Métamorphique des Pyrénées, Doctoral Dissertation, Université d'Orléans, $643 \mathrm{p}$.

Duretz, T, Asti R, Lagabrielle Y, Brun JP, Jourdon A, Clerc C, Corre B. 2019. Numerical modelling of Cretaceous Pyrenean Rifting: the interaction between mantle exhumation and syn-rift salt tectonics. Basin Research. DOI: 10.1111/bre.12389. 
Engvik AK, Austrheim H. 2010. Formation of sapphirine and corundum in scapolitised and Mg-metasomatised gabbro. Terra Nova 22(3): 166-171.

Espurt N, Callot JP, Totterdell J, Struckmeyer H, Vially R. 2009. Interactions between continental breakup dynamics and large-scale delta system evolution: insights from the Cretaceous Ceduna delta system, Bight Basin, Southern Australian margin. Tectonics 28(6).

Fabriès J, Lorand JP, Bodinier JL, Dupuy C. 1991. Evolution of the upper mantle beneath the Pyrenees: evidence from orogenic spinel lherzolite massifs. Journal of Petrology (2): 55-76.

Fallourd S, Poujol M, Boulvais P, Paquette JL, de Saint Blanquat M, Remy P. 2014. In situ LA-ICP-MS U-Pb titanite dating of $\mathrm{Na}-\mathrm{Ca}$ metasomatism in orogenic belts: the North Pyrenean example. International Journal of Earth Sciences 103(3): 667-682.

Feneyrol J. 2012. Pétrologie, géochimie et genèse des gisements de tsavorite associés aux gneiss et roches calco-silicatées graphiteux de Lemshuku et Namalulu, Tanzanie, Doctoral dissertation, Université de Lorraine, $885 \mathrm{p}$.

García Senz J. 2002. Cuencas extensivas del Cretácico Inferior en los Pirineos centrales. Formación y subsecuente inversión. Universitat de Barcelona

Garrido-Megías A. 1972. Síntesis geológica del Secundario y Terciario entre los ríos Cinca y Segre (Pirineo central de la vertiente surpirenaica, provincias de Huesca y Lérida). Boletín Geológico y Minero de España 83: 1-47.

Gasparik T. 1994. A petrogenetic grid for the system MgO-Al2O3$\mathrm{SiO}$. The Journal of Geology 102(1): 97-109.

Gillard M, Manatschal G, Autin J. 2016. How can asymmetric detachment faults generate symmetric Ocean Continent Transitions? Terra Nova 28(1): 27-34.

Gleizes G. 1971. Étude géologique et minéralogique du Trias de Betchat et de Bonrepaux (Ariège), Thèse de troisième cycle, Université Paul-Sabatier - Toulouse III and Bureau des Recherches Géologiques et Minières, $121 \mathrm{p}$.

Golberg JM, Maluski H. 1988. Données nouvelles et mise au point sur l'âge du métamorphisme pyrénéen $=$ Age of the Pyrenean metamorphism: new data and discussion. Comptes Rendus de l'Académie des Sciences 306(6): 429-435.

Golberg JM, Leyreloup AF. 1990. High temperature-low pressure Cretaceous metamorphism related to crustal thinning (Eastern North Pyrenean Zone, France). Contributions to Mineralogy and Petrology 104: 194-207.

Gong Z, Langereis CG, Mullender TAT. 2008. The rotation of Iberia during the Aptian and the opening of the Bay of Biscay. Earth and Planetary Science Letters 273: 80-93.

Grew ES. 1988. Kornerupine at the Sar e Sang, Afghanistan, whiteschist locality: implications for tourmaline-kornerupine distribution in metamorphic rocks. American Mineralogist 73(3-4): 345-357.

Grew ES, Chernosky JV, Werding G, Abraham K, Marquez N, Hinthorne JR. 1990. Chemistry of kornerupine and associated minerals, a wet chemical, ion microprobe, and X-ray study emphasizing Li, Be, B and F contents. Journal of Petrology 31(5): 1025-1070.

Handy MR, Schmid SM, Bousquet R, Kissling E, Bernoulli D. 2010. Reconciling plate tectonic reconstructions of Alpine Tethys with the geological-geophysical record of spreading and subduction in the Alps. Earth-Science Reviews 102: 121-158.

Harley SL. 1993. Sapphirine granulites from the Vestfold Hills, East Antarctica: geochemical and metamorphic evolution. Antarctic Science 5(4): 389-402.

Harley SL, Motoyoshi Y. 2000. Al zoning in orthopyroxene in a sapphirine quartzite: evidence for $>1120{ }^{\circ} \mathrm{C}$ UHT metamorphism in the Napier Complex, Antarctica, and implications for the entropy of sapphirine. Contributions to Mineralogy and Petrology 138(4): 293-307.

Hawthorne FC, Cooper MA, Grew ES. 2009. The crystal chemistry of the kornerupite-prismatine series. III. Chemical relations. Canadian Mineralogist 47: 275-296.

Henry P, Azambre B, Montigny R, Rossy M, Stevenson RK. 1998. Late mantle evolution of the Pyrenean sub-continental lithospheric mantle in the light of new ${ }^{40} \mathrm{Ar}-{ }^{39} \mathrm{Ar}$ and $\mathrm{Sm}-\mathrm{Nd}$ ages on pyroxenites and peridotites (Pyrenees, France). Tectonophysics 296 (1-2): 103-123.

Jammes S, Manatschal G, Lavier L, Masini E. 2009. Tectonosedimentary evolution related to extreme crustal thinning ahead of a propagating ocean: example of the western Pyrenees. Tectonics 28 (4).

Jöns N, Schenk V. 2008. Relics of the Mozambique Ocean in the central East African Orogen: evidence from the Vohibory Block of southern Madagascar. Journal of Metamorphic Geology 26: 17 28.

Lacroix A. 1892. Sur l'axinite des Pyrénées, ses formes et les conditions de son gisement. Comptes Rendus de l'Académie des Sciences, 739-741.

Lacroix A. 1894. Les phénomènes de contact de la lherzolite et de quelques ophites des Pyrénées. Bulletin du Service de la Carte Géologique de France 6: 307-346.

Lacroix A. 1900. Les roches basiques accompagnant les lherzolites et les ophites des Pyrénées. Comptes Rendus du VIIIe Congrès Géologique International.

Lagabrielle Y, Bodinier JL. 2008. Submarine reworking of exhumed subcontinental mantle rocks: field evidence from the Lherz peridotites, French Pyrenees. Terra Nova 20: 11-21.

Lagabrielle Y, Labaume P, de Saint Blanquat M. 2010. Mantle exhumation, crustal denudation, and gravity tectonics during Cretaceous rifting in the Pyrenean realm (SW Europe): Insights from the geological setting of the lherzolite bodies. Tectonics 29(4).

Lagabrielle Y, Clerc C, Vauchez A, et al. 2016. Very high geothermal gradient during mantle exhumation recorded in mylonitic marbles and carbonate breccias from a Mesozoic Pyrenean paleomargin (Lherz area, North Pyrenean Zone, France). Comptes Rendus de Géoscience 348: 290-300.

Lagabrielle Y, Asti R, Fourcade S, et al. 2019. Mantle exhumation at magma-poor passive continental margins. Part I. 3D architecture and metasomatic evolution of a fossil exhumed mantle domain (Urdach lherzolite, north-western Pyrenees, France). Bulletin de la Société Géologique de France 190(1): 8.

Lago M, Arranz E, Pocovi A, Galé C, Gil-Imaz, A. 2004. Permian magmatism and basin dynamics in the southern Pyrenees: a record of the transition from late Variscan transtension to early Alpine extension. Geological Society, London, Special Publications 223 (1): 439-464.

Le Roux V, Bodinier JL, Tommasi A, et al. 2007. The Lherz spinel lherzolite: refertilized rather than pristine mantle. Earth and Planetary Science Letters 259(3): 599-612.

Masini E, Manatschal G, Tugend J, Mohn G, Flament JM. 2014. The tectono-sedimentary evolution of a hyper-extended rift basin: the example of the Arzacq-Mauléon rift system (Western Pyrenees, SW France). International Journal of Earth Sciences 103(6): 1569-1596.

McClay KR, Whitehouse PS, Dooley T, Richards M. 2004. 3D evolution of fold and thrust belts formed by oblique convergence. Marine and Petroleum Geology 21(7): 857-877.

Meinhold G. 2010. Rutile and its applications in earth sciences. EarthScience Reviews 102(1-2): 1-28. 
Mezger K, Hanson GN, Bohlen SR. 1989. High precision U-Pb ages of metamorphic rutile: applaication to the cooling history of highgrade terranes. Earth and Planetary Science Letters 96: 106-118.

Minnigh LD, Van Calsteren PWC, Den Tex E. 1980. Quenching: An additional model for emplacement of the Iherzolite at Lers (French Pyrenees). Geology 8(1): 18-21.

Monchoux P. 1969. Corindon, kornerupine, sapphirine. Bulletin de la Société française de Minéralogie et de Cristallographie 92: 397-399.

Monchoux P. 1970. Les lherzolites pyrénéennes: contribution à l'étude de leur minéralogie, de leur genèse et de leurs transformations. Doctoral Dissertation, Université de Toulouse, $180 \mathrm{p}$.

Monchoux P. 1972a. Roches à sapphirine au contact des lherzolites pyrénéennes. Contributions to Mineralogy and Petrology 37: 47-64.

Monchoux P. 1972b. Description des gisements de sapphirine associés aux lherzolites pyrénéennes : I. Gisements de l'étang de Lherz. Bulletin de la Société d'Histoire Naturelle de Toulouse: 410-419.

Montigny R, Azambre B, Rossy M, Thuizat R. 1986. K-Ar study of cretaceous magmatism and metamorphism in the Pyrenees: age and length of rotation of the Iberian Peninsula. Tectonophysics 129: 257-213.

Moore, PB. 1969. The crystal structure of sapphirine. American Mineralogist: Journal of Earth and Planetary Materials 54(1-2): 31-49.

Morishita T, Arai S, Gervilla F. 2001. High-pressure aluminous mafic rocks from the Ronda peridotite massif, southern Spain: significance of sapphirine-and corundum-bearing mineral assemblages. Lithos 57(2-3): 143-161.

Nijland TG, Touret JL, Visser D. 1998. Anomalously low temperature orthopyroxene, spinel, and sapphirine occurrences in metasediments from the Bamble amphibolite-to-granulite facies transition zone (South Norway): possible evidence for localized action of saline fluids. The Journal of Geology 106(5): 575-590.

Olivet JL. 1996. La cinématique de la plaque ibérique. Bulletin des Centres de Recherche Exploration-Production Elf-Aquitaine 20: 131-195.

Péron-Pinvidic G, Manatschal G. 2009. The final rifting evolution at deep magma-poor passive margins from Iberia-Newfoundland: a new point of view. International Journal of Earth Sciences 98(7): 1581-1597.

Péron-Pinvidic G, Osmundsen PT. 2016. Architecture of the distal and outer domains of the Mid-Norwegian rifted margin: Insights from the Rån-Gjallar ridges system. Marine and Petroleum Geology 77: 280-299.

Podlesskii KK, Aranovitch LY, Gerya TV, Kosyakova NA. 2008. Sapphirine-bearing assemblages in the system $\mathrm{MgO}-\mathrm{Al}_{2} \mathrm{O}_{3}-\mathrm{SiO}_{2}$ : a continuing ambiguity. European Journal of Mineralogy 20: 721-734.

Podlesskii KK. 2010. Stability of sapphirine-bearing mineral assemblages in the system $\mathrm{FeO}-\mathrm{MgO}-\mathrm{Al}_{2} \mathrm{O}_{3}-\mathrm{SiO}_{2}$ and metamorphic $\mathrm{P}-\mathrm{T}$ parametres of aluminous granulites. Petrology 18: 350-368.

Poujol M, Boulvais P, Kosler J. 2010. Regional-scale Cretaceous albitization in the Pyrenees: evidence from in situ $\mathrm{U}-\mathrm{Th}-\mathrm{Pb}$ dating of monazite, titanite and zircon. Journal of the Geological Society of London 167: 751-767.

Ravier J. 1959. Le métamorphisme des terrains secondaires des Pyrénées. Mémoires de la Société Géologique de France 86: 250 p.

Ravier J, Thiébaut J. 1982. Sur l'origine lagunaire des marbres et cornéennes mésozoïques du col d'Agnes (Ariège). Comptes Rendus de l'Académie des Sciences 294: 127-130.
Rosenbaum G, Lister GS, Duboz C. 2002. Relative motions of Africa, Iberia and Europe during Alpine orogeny. Tectonophysics 359: $117-129$.

Roux L. 1977. L'évolution des roches du faciès granulite et le problème des ultramafitites dans le massif de Castillon (Ariège), Doctoral Dissertation, Université de Toulouse, 487 p.

Salardon R, Carpentier C, Bellahsen N, Pironon J, France-Lanord C. 2017. Interactions between tectonics and fluid circulations in an inverted hyper-extended basin: Example of mesozoic carbonate rocks of the western North Pyrenean Zone (Chaînons Béarnais, France). Marine and Petroleum Geology 80: 563-586.

Saspiturry N, Razin P, Baudin T, Serrano O, Issautier B, Lasseur E, et al. 2019. Symmetry vs. asymmetry of a hyper-thinned rift: example of the Mauléon Basin (Western Pyrenees, France). Marine and Petroleum Geology 104: 86-105.

Schärer U, Parseval PD, Polvé M, de Saint Blanquat M. 1999. Formation of the Trimouns talc-chlorite deposit (Pyrenees) from persistent hydrothermal activity between 112 and 97 Ma. Terra Nova 11(1): 30-37.

Schreyer W, Abraham K. 1976. Three-stage metamorphic history of a whiteschist from Sar e Sang, Afghanistan, as part of a former evaporite deposit. Contributions to Mineralogy and Petrology 59 (2): $111-130$.

Seifert F. 1974. Stability of sapphirine: a study of the aluminous part of the system MgO-A12O3-SiO2-H2O. The Journal of Geology 82 (2): 173-204.

Sibuet JC, Srivastava S, Manatschal G. 2007. Exhumed mantleforming transitional crust in the Newfoundland-Iberia rift and associated magnetic anomalies. Journal of Geophysical Research 112: B06105.

Simon G, Chopin C. 2001. Enstatite-sapphirine crack-related assemblages in ultrahigh-pressure pyrope megablasts, Dora-Maira Massif, western Alps. Contributions to Mineralogy and Petrology 140: $422-440$.

Stacey JS, Kramers JD. 1975 Approximation of terrestrial lead isotope evolution by a two-stage model. Earth and Planetary Science Letters 26: 207-221.

Ternet Y, Colchen M, Debroas EJ, et al. 1997. Notice explicative, Carte géologique de France (1/50 000), feuille 1086, Aulus-les-Bains. Orléans: BRGM éditions, Bureau des Recherches Géologiques et Minières.

Thiébaut J, Debeaux M, Durand-Wackenheim C, et al. 1988. Métamorphisme et halocinèse crétacés dans les évaporites de Betchat le long du chevauchement frontal nord-Pyrénéen (HauteGaronne et Ariège, France). Comptes rendus de l'Académie des sciences, Série 2 307: 1535-1540.

Thiébaut J, Durand-Wackenheim C, Debeaux M, Souquet P. 1992. Métamorphisme des évaporites triasiques du versant nord des Pyrénées centrales et occidentales. Bulletin de la Société d'Histoire Naturelle de Toulouse 128: 77-84.

Tugend J, Manatschal G, Kusznir NJ, Masini E. 2015. Characterizing and identifying structural domains at rifted continental margins: application to the Bay of Biscay margins and its Western Pyrenean fossil remnants. Geological Society, London, Special Publications 413(1): 171-203.

Vauchez A, Clerc C, Bestani L, et al. 2013. Preorogenic exhumation of the North Pyrenean Agly massif (Eastern Pyrenees-France). Tectonics 32: 1-12.

Vielzeuf D, Kornprobst J. 1984. Crustal splitting and the emplacement of Pyrenean lherzolites and granulites. Earth Planetary Science Letters 67(1): 87-96.

Vry JK, Cartwright I. 1994. Sapphirine-kornerupine rocks from the Reynolds Range, central Australia: constraints on the uplift history 
of a Proterozoic low pressure terrain. Contributions to Mineralogy and Petrology 116(1-2): 78-91.

Wheller CJ, Powell R. 2014. A new thermodynamic model for sapphirine: calculated phase equilibria in $\mathrm{K}_{2} \mathrm{O}-\mathrm{FeO}-\mathrm{MgO}-\mathrm{Al}_{2} \mathrm{O}_{3}-$ $\mathrm{SiO}_{2}-\mathrm{H}_{2} \mathrm{O}-\mathrm{TiO}_{2}-\mathrm{Fe}_{2} \mathrm{O}_{3}$. Journal of Metamorphic Geology 32: 287-299.
Whitney DL, Evans BW. 2010. Abbreviations for names of rockforming minerals. American Mineralogist 95: 185-187.

Windley BF, Ackermand D, Herd RK. 1984. Sapphirine/kornerupinebearing rocks and crustal uplift history of the Limpopo belt, Southern Africa. Contributions to Mineralogy and Petrology 86(4): 342-358.

Cite this article as: Uzel J, Lagabrielle Y, Fourcade S, Chopin C, Monchoux P, Clerc C, Poujol M. 2020. The sapphirine-bearing rocks in contact with the Lherz peridotite body: New mineralogical data, age and interpretation, BSGF - Earth Sciences Bulletin 191: 5. 